Nova Southeastern University

Florida

NSUWorks

$1-1-2012$

\title{
Beyond the First Amendment: Shaping the Contours of Commercial Speech in Video Games, Virtual Worlds and Social Media
}

Jon M. Garon

Follow this and additional works at: https://nsuworks.nova.edu/law_facarticles

\section{Recommended Citation}

Jon M. Garon, Beyond the First Amendment: Shaping the Contours of Commercial Speechin Video Games, Virtual Worlds and Social Media, 2012 UTAH L. REV. 607 (2012).

This Article is brought to you for free and open access by the Shepard Broad College of Law at NSUWorks. It has been accepted for inclusion in Faculty Scholarship by an authorized administrator of NSUWorks. For more information, please contact nsuworks@nova.edu. 


\section{UTAH LAW REVIEW}

TABLE OF CONTENTS

LEARY LECTURE

The Paradox of Political Power:

Same-Sex Marriage and the Supreme Court

Kenji Yoshino

527

ARTICLES

Climate Change, Political Truth, and the Marketplace of Ideas .

Karl S. Coplan

Beyond the First Amendment:

Shaping the Contours of Commercial Speech in

Video Games, Virtual Worlds, and Social Media

Jon M. Garon

607

Informing and Reforming the Marketplace of Ideas:

The Public-Private Model for Data Production

and the First Amendment

Shubha Ghosh

653

The Constitutionality of Lame-Duck Lawmaking: The Text, History, Intent, and Original Meaning of the Twentieth Amendment

Edward J. Larson

Innovation and International Commons:

The Case of Desalination

Under International Law

Rhett B. Larson

759

Federal Jurisdiction in Sports Labor Disputes

Michael H. LeRoy

815

Taking Outcomes Seriously

Daphna Lewinsohn-Zamir 861

The Sophisticates: Conflicted Representation and the Lehman Bankruptcy

Milan Markovic

903

Criminal Child Neglect and the "Free Range Kid":

Is Overprotective Parenting

the New Standard of Care?

David Pimentel

Moral Turpitude

Julia Ann Simon-Kerr 1001 
NOTE

The Fraud Enforcement and Recovery Act of 2009 and the Expansion of Liability

Under the False Claims Act

Cynthia Love

1129 


\title{
BEYOND THE FIRST AMENDMENT: \\ SHAPING THE CONTOURS OF COMMERCIAL SPEECH IN Video Games, VirTual Worlds, AND SOCIAL MEDIA
}

\author{
Jon M. Garon* \\ "What is one man's amusement, teaches another's doctrine."
}

\section{INTRODUCTION}

We are nearing the convergence of all media. ${ }^{2}$ Video games, virtual worlds, social media, and mobile apps have joined the litany of public entertainment alongside theatre, dance, music, art displays, film, and television. Sometimes described as transmedia, the phenomenon merely reflects that the streams of commerce have crossed and content producers and advertisers can no longer differentiate works based on their technological format ${ }^{3}$ or the windows of distribution. ${ }^{4}$

* (C) 2012 Jon M. Garon. Director, NKU Chase Law + Informatics Institute and Professor of Law, Northern Kentucky University Salmon P. Chase College of Law, J.D. Columbia University School of Law 1988. First prepared in conjunction with Michigan State University and Georgetown University, Governance of Social Media, A Quello Center Workshop (November 11-12, 2011). Special thanks to Jeannine Abukhater Lambert and Luke Bubenzer for their assistance with the development of these materials.

${ }^{1}$ Winters v. New York, 333 U.S. 507, 510 (1948).

${ }^{2}$ See, e.g., Brown v. Entm't Merch. Ass'n., 131 S. Ct. 2729, 2733 (2011) ("Like the protected books, plays, and movies that preceded them, video games communicate ideasand even social messages-through many familiar literary devices . . .."); FTC Guides Concerning the Use of Endorsements and Testimonials in Advertising, 74 Fed. Reg. 53,124, 53,125-26 (Oct. 15, 2009) (codified at 16 C.F.R. pt. 255) (describing how new forms of media are pushing the limits of current regulations as they are introduced into the marketplace); Over 70\% of Teens and Young Adults Shout "Hey Dude, I Still Want a Laptop!," PhX. CONVERged TeCH. \& MEdiA (Oct. 24, 2011), http://www.phoenixmi.com/ ctmblog/?p=35/ ("“[L]aptops are in high demand" . . . [while].9\% of current adult Paid TV subscribers report being likely to discontinue Paid TV [in favor of] streaming TV shows and movies from the Internet.").

${ }^{3}$ See, e.g., Rebecca Tushnet, Attention Must Be Paid: Commercial Speech, UserGenerated Ads, and the Challenge of Regulation, 58 BuFF. L. REV. 721, 731 (2010) ("So far, courts have found commercial speech doctrine applicable to new ad formats, where the alternative would be to allow false and misleading commercial claims to be virtually immune from regulation.").

${ }^{4}$ See Jon M. Garon, Content, Control, and the Socially Networked Film, 48 U. LOUISVILLE L. REV. 771, 790 (2010) (“A typical distribution sequence for a major's film in the USA will be an initial theatrical release of around six months, followed by a DVD/video window[,] . . pay-per-view telecasts[,] . . a premium cable movie channel window (for approximately one year), a network TV window[,] and, finally, a syndicated 
As First Amendment jurisprudence has evolved, it has also grown to extend into traditional entertainment media. and into purely commercial speech. ${ }^{6}$ "Like the protected books, plays, and movies that preceded them, video games communicate ideas-and even social messages - through many familiar literary devices . . . "7 The expansion of First Amendment coverage and shrinkage of commercial speech exceptions have converged in the video game industry and in online, interactive media, creating new challenges to the understanding of content regulation, ownership, and consumer protection. ${ }^{8}$

At both the state and federal level, the traditional rules of content regulation are straining under First Amendment concerns for interactive media. State courts have sought out copyright-like accommodations for publicity rights while at the same time the Federal Trade Commission (FTC) has increased its regulatory mandate for new media.

This problem is not new. Though "the basic principles of freedom of speech" are not new, they are sometimes strained by a "new and different medium of communication." At the same time, newspapers have traditionally received the most robust of First Amendment protections, ${ }^{10}$ but such regulatory protection does

TV window." (quoting AN INTRODUCTION TO Film Studies 21 (Jill Nelmes ed., 3d ed. 2003)) (internal quotation marks omitted)).

${ }^{5}$ See Joseph Burstyn, Inc. v. Wilson, 343 U.S. 495, 502-03 (1952) (addressing the regulation of motion pictures, the court stated that "the basic principles of freedom of speech and the press, like the First Amendment's command, do not vary."); United States v. Paramount Pictures, Inc., 334 U.S. 131, 166 (1948) ("We have no doubt that moving pictures, like newspapers and radio, are included in the press whose freedom is guaranteed by the First Amendment.").

${ }^{6}$ Cent. Hudson Gas \& Elec. Corp. v. Pub. Serv. Comm'n, 447 U.S. 557, 569-72 (1980) (holding that restrictions on commercial speech must be "no more extensive than necessary to further the State's interest").

${ }^{7}$ Brown, 131 S. Ct. at 2733.

${ }^{8}$ See, e.g., C.B.C. Distrib. \& Mktg. v. Major League Baseball Advanced Media, L.P., 505 F.3d 818 (8th Cir. 2007) (finding First Amendment rights of a fantasy baseball website supersedes player privacy rights to names and statistics); Hart v. Elec. Arts, Inc., $808 \mathrm{~F}$. Supp. 2d 757 (D.N.J. 2011) (dismissing college athlete's claim against video game manufacturer for depiction in the game without consent); In re NCAA Student-Athlete Name \& Likeness Licensing Litig., No. C 09-01967, 2011 WL 3240518 (N.D. Cal. July 28, 2011) (denying Electronic Arts' motion to dismiss an antitrust suit involving the NCAA and Electronic Arts over agreements to bar payment to current and former student athletes); Kirby v. Sega of Am., Inc., 50 Cal. Rptr. 3d 607 (Ct. App. 2006) (holding the First Amendment provided "a complete defense" to celebrity plaintiff's claim of misappropriation of likeness).

${ }^{9}$ Brown, 131 S. Ct. at 2733 (quoting Joseph Burstyn, 343 U.S. at 503).

${ }^{10}$ See N.Y. Times Co. v. Sullivan, 376 U.S. 254, 266 (1964); Near v. Minnesota ex rel. Olson, 283 U.S. 697, 715 (1931). 
not eliminate the obligation to prohibit fraudulent advertisements or the ability to tax the sale of newspapers. ${ }^{11}$

By looking at these two trends and the surrounding constitutional jurisprudence, it may be possible to develop a new approach to commercial regulation of interactive media that provides predictable rules and useful commercial markers for industry. Part I of this Article reviews the Court's expansion of the First Amendment from newspapers to motion pictures, and finally to video games. Part II then compares the expansion of the First Amendment with the more modest development of free speech jurisprudence in the context of commercial speech. Part III looks at a particular aspect of commercial speech regulation in the context of Federal Communications Commission (FCC) and FTC regulations of commercial content. And Part IV then builds upon this existing regulatory framework to suggest a reformulation of publicity rights that are consistent with the Constitution, the interests of the public, and the rights of individuals to control their rights of publicity.

\section{INTERACTIVE IS NOT EXCEPTIONAL-SO IT NEEDS No GREATER REGULATION}

Throughout history, critics of broader First Amendment protection have suggested that new forms of entertainment should be afforded only limited legal protection. ${ }^{12}$ In Mutual Film Corp. v. Industrial Commission, ${ }^{13}$ (generally referred to as "The Mutual"), the Supreme Court had an early opportunity to provide broad free speech protections for film. ${ }^{14}$ The Court took a very different approach:

Are moving pictures within the [First Amendment] principle, as it is contended they are? They, indeed, may be mediums of thought, but so are many things. So is the theatre, the circus, and all other shows and spectacles, and their performances may be thus brought by the like reasoning under the same immunity from repression or supervision as the public press, - - made the same agencies of civil liberty....

We immediately feel that the argument is wrong or strained which extends the guaranties of free opinion and speech to the multitudinous

"See Minn. Star \& Tribune Co. v. Minn. Comm'r of Revenue, 460 U.S. 575, 581 (1983) ("Clearly, the First Amendment does not prohibit all regulation of the press. It is beyond dispute that the States and the Federal Government can subject newspapers to generally applicable economic regulations without creating constitutional problems."); see also Globe Newspaper Co. v. Comm'r of Revenue, 571 N.E.2d 617, 618 (Mass. 1991) (striking down a discriminatory tax as a violation of the First Amendment).

${ }_{12}^{12}$ The issue is actually far older. Consider Plato, The RePUBliC OF Plato 81-82 (John Llewelyn Davies \& David James Vaughan, trans., MacMillan \& Co. 3d ed. 1866) ("[C]an we approve of ... insolent expressions which in prose or in poetry are put into the mouths of inferiors towards those in authority? No, we cannot. Because, I imagine, they do not tend to promote sobriety in youth.").

\footnotetext{
${ }^{13} 236$ U.S. 230 (1915).

${ }^{14}$ Id. at 239.
} 
shows which are advertised on the bill-boards of our cities and towns ... and which seeks to bring motion pictures and other spectacles into practical and legal similitude to a free press and liberty of opinion. ${ }^{15}$

This approach was rejected in dicta thirty-three years later in $1948,{ }^{16}$ and by a decision four years after that. ${ }^{17}$ But even after rejecting exclusion of First Amendment protection for motion pictures, the Court was unwilling to abandon all concerns regarding this potentially insidious medium:

To hold that liberty of expression by means of motion pictures is guaranteed by the First and Fourteenth Amendments, however, is not the end of our problem. It does not follow that the Constitution requires absolute freedom to exhibit every motion picture of every kind at all times and all places. ... Nor does it follow that motion pictures are necessarily subject to the precise rules governing any other particular method of expression. Each method tends to present its own peculiar problems. ${ }^{18}$

Courts, along with Congress and federal regulators, have continued to struggle with exceptional concerns regarding various media such as radio ${ }^{19}$ and television. ${ }^{20}$

Just as motion pictures were once thought exceptional because of their vividness and insidious ability to shape opinion while entertaining, and television

${ }^{15} \mathrm{Id}$. at 243-44. Interestingly, the Court had no reason to address this issue since it had yet to reach state laws under the First Amendment. See Gitlow v. New York, 268 U.S. 652,666 (1925) (providing for the first time liberty of speech and of the press as within the Due Process Clause of the Fourteenth Amendment).

${ }^{16}$ United States v. Paramount Pictures, Inc., 334 U.S. 131, 166 (1948) (upholding broad antitrust action against motion picture studios).

${ }^{17}$ Joseph Burstyn, Inc. v. Wilson, 343 U.S. 495, 502-03 (1952).

${ }^{18} I d$.

19 See, e.g., FCC v. Pacifica Found., 438 U.S. 726 (1978) (upholding fine and prohibition for broadcast of George Carlin's "Seven Dirty Words" comedy routine). In FCC v. Fox Television Stations, Inc., 132 S. Ct. 2307 (2012), the Supreme Court struck down the regulations regarding the amendments to the broadcast indecency guidelines. Id. at 2318. The Court found the notice and application process violated the Due Process Clause of the Fifth Amendment. Id. at 2317-18. Although the Court had earlier upheld the regulation from attack under the Administrative Procedure Act, it had remanded for the lower courts to address the constitutional issues. Id. at 2320. In a short concurrence Justice Ginsburg called into question the continuing validity of Pacifica. Id. at 2321 (Ginsburg, J., concurring).

${ }^{20}$ See, e.g., Red Lion Broad. Co. v. FCC, 395 U.S. 367, 390 (1969) (regulating broadcast television under scarcity doctrine). To the extent that the Court struck down the current indecency regulations in Fox Television Stations, the continued reliance on the scarcity doctrine is even more tenuous. The particular doctrine involved in Fox Television Stations and Red Lion does not directly apply to video games, virtual worlds, or social media. See Fox Television Stations, 132 S. Ct. at 2307; Red Lion, 395 U.S. at 367. 
has been treated as exceptional because of its pervasiveness and ubiquity in the home, questions have persisted that video games and Internet content are exceptional because of their interactivity. "Virtual worlds are something different from traditional forms of media . . . The most compelling element of virtual worlds, it turns out, is not the powerful graphic technologies they employ but the very real social interactions that occur through that technology.",22 Concerned about the uniquely immersive nature of video games, legislatures in several states tried to protect minors by prohibiting violent, first-person shooter or sexually offensive video games. ${ }^{23}$

The Supreme Court addressed this issue directly when it struck down the California law regulating access of violent video games to minors. In Brown v. Entertainment Merchants Ass' $n,{ }^{24}$ the Supreme Court rejected the argument that interactive video games represent an exceptional medium requiring additional regulation. ${ }^{25}$ The Court dismissed the argument almost out of hand: "As for the argument that video games enable participation in the violent action, that seems to us more a matter of degree than of kind."26

Moreover, as the Brown Court emphasized, Congress and state legislatures are constitutionally incapable of expanding the categories of speech unprotected by the First Amendment:

Last Term, in [United States v.] Stevens, we held that new categories of unprotected speech may not be added to the list by a legislature that concludes certain speech is too harmful to be tolerated... The Government argued in Stevens that lack of a historical warrant did not matter; that it could create new categories of unprotected speech by applying a "simple balancing test" that weighs the value of a particular category of speech against its social costs and then punishes that

${ }^{21}$ Brown v. Entm't Merchs. Ass'n, 131 S. Ct. 2729, 2737-38 (2011) (“California claims that video games present special problems because they are 'interactive,' in that the player participates in the violent action on screen and determines its outcome.").

${ }^{22}$ Greg Lastowka, Virtual Justice: The New Laws of Online Worlds 9-10 (2010).

${ }^{23}$ GERALD BARRETT, OfFICE OF LEGISLATIVE RESEARCH, 2008-R-0233, LEGISLATION ON VideO GAME VIOLENCE 1 (Conn. 2008), available at http://www.cga.ct .gov/2008/rpt/2008-R-0233.htm ("California, Georgia, Illinois, Louisiana, Maryland, Michigan, Minnesota, Oklahoma, and Washington, have passed laws regulating the sale of violent or sexually explicit video games."); see Interactive Digital Software Ass'n v. St. Louis Cnty., 329 F.3d 954, 956 (8th Cir. 2003) (discussing a St. Louis County ordinance making it unlawful for any person knowingly to sell, rent, or make available graphically violent video games to minors); Am. Amusement Mach. Ass'n v. Kendrick, 244 F.3d 572, 573 (7th Cir. 2001) (discussing an Indianapolis ordinance limiting access of minors to video games that depict violence).

\footnotetext{
${ }^{24} 131$ S. Ct. 2729.

${ }^{25} \mathrm{Id}$. at $2737-38$.

${ }^{26} \mathrm{Id}$. at 2738.
} 
category of speech if it fails the test. We emphatically rejected that "startling and dangerous" proposition. ${ }^{27}$

The implications of Stevens on new technological innovation and communication were squarely before the Court in Brown, and the Court's depiction of video game violence as different in degree rather than kind suggests a jurisprudence that will reject any claims of technological exceptionalism. As viewed by the Brown and Stevens courts, legislative action cannot reduce the scope of the First Amendment. Since the Court will reject all claims of exceptionalism and it will not permit efforts to expand the categories of unprotected speech, the regulation of video games and virtual worlds will be treated the same as it is for other media. Where these media involve commercial activities, therefore, the traditional Supreme Court jurisprudence on commercial speech applies.

\section{COMmercial SpeECh Retains InTERMEdiate SCRUTINy-For Now}

Traditionally, in cases that are predominantly commercial, the Supreme Court has applied an intermediate standard of scrutiny. ${ }^{28}$ As explained in Central Hudson Gas \& Electric Corp. v. Public Service Commission,

Commercial expression not only serves the economic interest of the speaker, but also assists consumers and furthers the societal interest in the fullest possible dissemination of information. In applying the First Amendment to this area, we have rejected the "highly paternalistic" view that government has complete power to suppress or regulate commercial speech....

Nevertheless, our decisions have recognized 'the 'commonsense' distinction between speech proposing a commercial transaction, which occurs in an area traditionally subject to government regulation, and other varieties of speech."29

Under the Central Hudson test, "government laws and regulations may significantly restrict speech, as long as they also 'directly advance' a 'substantial'

${ }^{27}$ Id. at 2734 (citing United States v. Stevens, 120 S. Ct. 1577 (2010)) ("Stevens concerned a federal statute purporting to criminalize the creation, sale, or possession of certain depictions of animal cruelty. . . There was no American tradition of forbidding the depiction of animal cruelty-though States have long had laws against committing it." (citation omitted)).

${ }^{28}$ See Cent. Hudson Gas \& Elec. Corp. v. Pub. Serv. Comm'n, 447 U.S. 557, 563 (1980) (establishing First Amendment protection for commercial speech and recognizing right of recipients of commercial speech to have access to the content); see also Ohralik v. Ohio State Bar Ass'n, 436 U.S. 447 (1978) (upholding state lawyer advertising regulation); Va. State Bd. of Pharmacy v. Va. Citizens Consumer Council, Inc., 425 U.S. 748, 771-72 (1976) (evaluating prescription drug advertising statute using intermediate scrutiny).

${ }^{29}$ Cent. Hudson, 447 U.S. at 561-62 (quoting Ohralik, 436 U.S. at 455-56). 
government interest that could not "be served as well by a more limited restriction." ${ }^{30}$ Despite the continued support for the language of the Central Hudson test, the Court often signals ambivalence about the continued vitality of its distinction. ${ }^{31}$

Building on the Stevens approach to the First Amendment, in Sorrell v. IMS Health Inc., ${ }^{32}$ the Supreme Court invalidated a Vermont law barring the sale of doctor prescription information to pharmaceutical companies for the purpose of marketing prescription drugs to doctors. ${ }^{33}$ The law was designed to stop the practice of detailing-a form of commercial profiling-whereby pharmaceutical companies would target sales to doctors of prescription drugs based on their prescription history. ${ }^{34}$

While the purpose of the law focused on the sales methodology, the subject of the law focused on the access to information held by medical institutions. Moreover, the law was not a ban on the practice. Instead it required prescriber consent to the distribution of the information. ${ }^{35}$ Nonetheless, the law singled out the pharmaceutical companies for their later use of the content. The Supreme Court invalidated the law as a viewpoint-based restriction:

The legislature designed $\S 4631(\mathrm{~d})$ to target those speakers and their messages for disfavored treatment. "In its practical operation," Vermont's law "goes even beyond mere content discrimination, to actual viewpoint discrimination." Given the legislature's expressed statement of purpose, it is apparent that $\S 4631$ (d) imposes burdens that are based on the content of speech and that are aimed at a particular viewpoint.

[The statute] is designed to impose a specific, content-based burden on protected expression. It follows that heightened judicial scrutiny is warranted. ${ }^{36}$

The dissent raised concerns that the characterization was misplaced and greater emphasis should have been directed at the commercial nature of the statute. As the dissent pointed out, "our cases make clear that the First Amendment offers

${ }^{30}$ Sorrell v. IMS Health Inc., 131 S. Ct. 2653, 2673 (2011) (Breyer, J., dissenting) (quoting Cent. Hudson, 447 U.S. at 564).

31 United States v. United Foods, 533 U.S. 405, 409-10 (2001) ("We have used standards for determining the validity of speech regulations which accord less protection to commercial speech than to other expression. That approach, in turn, has been subject to some criticism.") (citations omitted).

$32131 \mathrm{~S}$. Ct. 2653.

${ }^{33}$ Id. at 2659 ("Vermont law restricts the sale, disclosure, and use of pharmacy records that reveal the prescribing practices of individual doctors.").

${ }^{34} \mathrm{Id}$.

${ }^{35} I d$. at $2660 ; 18$ VT. STAT. ANN. tit. $18 \S 4631$ (Supp. 2011).

${ }^{36}$ Sorrell, 131 S. Ct. at 2664 (quoting R.A.V. v. St. Paul, 505 U.S. 377, 391 (1992)). 
considerably less protection to the maintenance of a free marketplace for goods and services.",37

The distinction is critical in the ongoing line-drawing for regulation of commercial-like speech in interactive media. Even intermediate scrutiny is not required, the dissent in Sorrell continued, for "'sales practices' that are 'misleading, deceptive, or aggressive." ${ }^{38}$ The majority, however, refused to consider the aggressive use of the information as sufficient to support the law.

The consequence may be a further narrowing of the situations under which the label commercial speech will protect a regulatory system from strict scrutiny under the First Amendment. ${ }^{39}$ As such, any regime distinguishing commercial from noncommercial conduct must be very cautious in its prophylactic use of commercial regulation.

Despite the caution suggested, the recent line of Supreme Court cases on the First Amendment has not limited or abandoned the distinction between commercial and noncommercial speech. While the Court has refused to permit new categories of unprotected speech, the decisions have not signaled an end to regulation of commercial activities involving speech. ${ }^{40}$ As such, now that video games are recognized as having full First Amendment protection, the role of publicity rights can best be understood as a form of commercial speech regulation by the states.

${ }^{37}$ Id. at 2674 (Breyer, J., dissenting); see Fla. Bar v. Went For It, Inc., 515 U.S. 618, 623 (1995) ("We have always been careful to distinguish commercial speech from speech at the First Amendment's core.").

${ }^{38}$ Sorrell, $131 \mathrm{~S}$. Ct. at 2674 (Breyer, J., dissenting) (quoting 44 Liquormart, Inc. v. Rhode Island, 517 U.S. 484, 501 (1996) (plurality opinion)).

${ }^{39}$ See, e.g., Rubin v. Coors Brewing Co., 514 U.S. 476 (1995) (striking down a ban on accurate disclosure of the alcohol content of beer and malt liquor). In a concurring opinion, Justice Stevens expressed doubt that the commercial speech doctrine applied to the case:

In my opinion the "commercial speech doctrine" is unsuited to this case, because the Federal Alcohol Administration Act (FAAA) neither prevents. misleading speech nor protects consumers from the dangers of incomplete information. A truthful statement about the alcohol content of malt beverages would receive full First Amendment protection in any other context; without some justification tailored to the special character of commercial speech, the Government should not be able to suppress the same truthful speech merely because it happens to appear on the label of a product for sale.

Id. at 491-92 (Stevens, J., concurring).

40 See, e.g., United States v. Alvarez, 123 S. Ct. 2537, 2554 (2012) (Breyer, J., concurring) (plurality opinion) ("Statutes prohibiting trademark infringement present, perhaps, the closest analogy to the present statute. . . But trademark statutes are focused upon commercial and promotional activities that are likely to dilute the value of a mark. Indeed, they typically require a showing of likely confusion, a showing that tends to assure that the feared harm will in fact take place."). 


\section{Commercial Regulation Remains Permissible- LESSONS OF THE FTC AND FCC}

From recent Supreme Court jurisprudence, it follows that the commercial regulation of video games, virtual worlds, and social media must be conducted with a deft and gentle hand if regulators hope to have the regulation survive constitutional scrutiny. Online publicity rights and the revised FTC endorsement guidelines provide an effective test-set of state and federal commercial regulation that affects free speech. The FTC guidelines have been more narrowly crafted and as such these may provide a way forward to avoid the more problematic jurisprudence developing regarding publicity rights. A review of various FTC regulations highlights the framework that exists for the regulation of commercial activities in video games, virtual worlds, and social media. Although there are aspects that may overstep constitutional authority, these guidelines generally provide a successful road map for navigating the challenges of constitutionality and commercial regulation.

\section{A. FTC's Incremental Growth in Governance of Online Commercial Speech}

Responding to the growing importance of consumer testimonials and the increased role of blogs and social media in marketing, the FTC amended and updated its Guides Concerning the Use of Endorsements and Testimonials in Advertising (FTC Endorsement Guidelines) in 2009. ${ }^{41}$ By their terms, the FTC Endorsement Guidelines provide "guidance [for] the public in conducting its affairs in conformity with legal requirements... [regarding] the use of endorsements and testimonials in advertising." remains the more general power of the FTC to regulate unfair trade practices under section 5 of the Federal Trade Commission Act (FTC Act). ${ }^{43}$ As such, FTC regulations state, "The Guides provide the basis for voluntary compliance with the law by advertisers and endorsers."

By their express terms, the FTC Endorsement Guidelines apply only to commercial speech. The provisions reach endorsements and testimonials in advertising, including "any product, service, company or industry." ${ }^{.45}$ They require "the honest opinions, findings, beliefs, or experience of the endorser."46 They prohibit false commercial speech by declaring that "an endorsement may not

${ }^{41}$ FTC Guides Concerning the Use of Endorsements and Testimonials in Advertising, 74 Fed. Reg. 53,124, 53,125 (Oct. 15, 2009) (codified at 16 C.F.R.pt. 255)

42 16 C.F.R. $\$ 255.0$ (a) (2012).

${ }^{43} 15$ U.S.C. $\$ 45$ (2006).

${ }^{44} 16$ C.F.R. $\$ 255.0(\mathrm{a})$.

${ }^{45}$ Id. $\S 255.0(\mathrm{~d})$.

${ }^{46}$ Id. § 255.1(a). 
convey any express or implied representation that would be deceptive if made directly by the advertiser." 47

The FTC Endorsement Guidelines also govern materially omitted information regarding any relationship between the advertiser and the endorser. "When there exists a connection between the endorser and the seller of the advertised product that might materially affect the weight or credibility of the endorsement (i.e., the connection is not reasonably expected by the audience), such connection must be fully disclosed., ${ }^{, 48}$ The examples include websites, social media, television, and blogs. Although the examples do not include video games, they are merely illustrative and not exhaustive. The FTC Endorsement Guidelines could certainly reach content in both video games and virtual worlds.

There is an open question whether the guidelines cover incidental gifts such as show tickets for reviewers, free shipping, discount coupons, or other items. To keep the guidelines within commercial speech contours, the materiality requirement for the endorsement connection should be taken seriously by the FTC. At least two student notes take the position that regulations reach noncommercial speech of bloggers when applied to these de minimis items. ${ }^{49}$

The guidance language providing a standard that requires disclosure if the consideration "might materially affect the weight or credibility of the endorsement" ${ }^{50}$ seems rather prophylactic and overbroad, given that the consequence is to compel speech-in the form of additional disclosure-by the party making the endorsement. Terms such as "might" seem much less rigorous than requiring "information that is important to consumers and, hence, likely to affect their choice of, or conduct regarding a product"- the standard the FTC applies in its actions. ${ }^{51}$

\author{
${ }^{47} \mathrm{Id}$. \\ ${ }^{48} I d . \S 255.5$. \\ 49 Jason Goldstein, Note, How New FTC Guidelines on Endorsement and
} Testimonials Will Affect Traditional and New Media, 28 CARDOZO ARTs \& ENT. L.J. 609, 626 (2011); Recent Regulation, Internet Law - Advertising and Consumer Protection FTC Extends Endorsement and Testimonial Guides to Cover Bloggers - 74 Fed. Reg. 53,124 (Oct. 15, 2009) (to be codified at 16 C.F.R. pt. 255), 123 HARV. L. REV. 1540, 1540 (2010).

${ }^{50}$ Cliffdale Assocs., Inc., 103 F.T.C. 110, 172 (1984).

${ }^{51} I d$. at 165 .

As noted in the Commission's policy statement, a material representation, omission, act or practice involves information that is important to consumers and, hence, likely to affect their choice of, or conduct regarding, a product. Consumers thus are likely to suffer injury from a material misrepresentation. A review of past Commission deception cases shows that one of the factors usually considered, either directly or indirectly, is whether or not a claim is material.

Id. at 165-66 (citations omitted). A footnote to the quoted text added that "an act or practice need only be likely to cause injury to be considered deceptive. Actual injury is not required." Id. at $166 \mathrm{n} .11$. 
When litigating claims, "[ $[$ ] deceptive advertising, asking whether '(1) a claim was made; (2) the claim was likely to mislead a reasonable consumer and (3) the claim was material.", Because the Guidelines act as mere guidance, the better interpretation is that disclosure of the connection between the seller and the endorser is the preferred path whenever there is the potential for misrepresentation. But the misrepresentation can only violate section 5 of the FTC Act if it rises to the level of materiality. Since a party will not be liable for violating the FTC Endorsement Guidelines, only the Act, such an understanding makes some sense, though it does suggest that the rulemaking has the potential to create a chilling effect on speech.

A second constitutional issue lurks within the FTC Endorsement Guidelines. Certain types of endorsements require less disclosure than other endorsements. The discrepancy is based on the presumed historical expectations of the reasonable consumer:

The Commission acknowledges that bloggers may be subject to different disclosure requirements than reviewers in traditional media. In general, under usual circumstances, the Commission does not consider reviews published in traditional media (i.e., where a newspaper, magazine, or television or radio station with independent editorial responsibility assigns an employee to review various products or services as part of his or her official duties, and then publishes those reviews) to be sponsored advertising messages. Accordingly, such reviews are not "endorsements" within the meaning of the Guides. Under these circumstances, the Commission believes, knowing whether the media entity that published the review paid for the item in question would not affect the weight consumers give to the reviewer's statements. ${ }^{53}$

This distinction-based on an untested factual assertion-could raise concerns even under a standard of intermediate scrutiny. ${ }^{54}$ To fit within the test, "the regulation must not 'distinguish favored speech from disfavored speech on the

52 Novartis Corp. v. FTC, 223 F.3d 783, 786 (D.C. Cir. 2000) (quoting the Commission's proceeding below); see also FTC v. Cantkier, 767 F. Supp. 2d 147, 153 (D.D.C. 2011) ("[T] he FTC is only required to allege a material representation, omission, or practice that is likely to mislead consumers acting reasonably under the circumstances.").

${ }^{53}$ FTC Guides Concerning the Use of Endorsements and Testimonials in Advertising, 74 Fed. Reg. 53,124, 53,136 (Oct. 15, 2009) (codified at 16 C.F.R. pt. 255) (footnotes omitted).

${ }^{54}$ See Turner Broad. Sys. v. FCC (Turner II), 520 U.S. 180, 189 (1997) ("A contentneutral regulation will be sustained under the First Amendment if it advances important governmental interests unrelated to the suppression of free speech and does not burden substantially more speech than necessary to further those interests." (citing United States v. O'Brien, 391 U.S. 367, 377 (1968))). 
basis of the ideas or views expressed." 55 Arguably, the FTC's distinction implies that traditional media reviews are less prone to coercion than consumer-based reviews, or that the assumed editorial policies of traditional media more effectively protect the public. ${ }^{56}$ The FTC does not explicitly endorse either of these positions, but the difference in regulation endorses a tiered value the FTC assumes exists among the public. By implication, the FTC is favoring traditional media over new media-newspaper and television critics over their counterparts on blogs and in social media.

As with the balance between broadcaster and cable operators at issue in Turner Broadcasting System, Inc. v. FCC, however, the mere existence of different guidance for the two categories is insufficient to require a strict scrutiny analysis of the guidance. ${ }^{57}$ In Turner, Congress provided substantial support for the important government interests at stake in the disparate treatment between cable operators and broadcasters. ${ }^{58}$ Were a court to find that the lack of such findings further suggested a content-based bias or a failure to meet the intermediate scrutiny standard, the FTC Endorsement Guidelines could be deemed unconstitutional. Additional guidance that eliminated the distinctions among media could readily remedy the disparate treatment, a step that is likely to occur as public perception about credibility becomes better documented.

Despite these two limited concerns over the constitutionality of the FTC Endorsement Guidelines, the guidelines are likely to meet the ongoing constitutional scrutiny precisely because the update to accommodate new media has not radically altered the approach taken by the FTC. Instead, the new approach has extrapolated well-established principles of materiality and the likelihood-tomislead standard for claims and omissions. ${ }^{59}$ By applying the established legal doctrine, the factual differences between traditional media and new media have little impact.

\section{B. FCC's Modest Role in Regulating Commercial Speech}

The FCC's active but limited authority to regulate commercial activities in broadcast media is another example of the constitutionality of the commercial regulation that may eventually be applied to video games, virtual worlds, and

${ }^{55}$ Turner II, 520 U.S. at 189 (quoting Turner Broad. Sys. v. FCC (Turner I), 512 U.S. 622,643 (1994)).

${ }^{56}$ Such an assumption may be significantly at odds with available data. See David Coursey, Microsoft Finds Friends Beat Experts on Buying Advice, Lose on Tech Support, FORBES (Nov. 2, 2011), http://www.forbes.com/sites/davidcoursey/2011/11/02/microsoftfinds-friends-beat-experts-on-buying-advice-lose-on-tech-support/ ("[W]ord-of-mouth is becoming more important as social media proliferates and the scope of our recommending 'friends' increases.").

${ }^{57}$ See Turner I, 512 U.S. at 646-49.

${ }^{58}$ Id. at 648.

${ }^{59}$ See Novartis Corp. v. FTC, 223 F.3d 783, 786 (D.C. Cir. 2000). 
social media. ${ }^{60}$ Regarding commercial speech, radio and television are regulated quite lightly. The primary regulation merely provides for the disclosure of broadcast sponsorship. ${ }^{61}$

[W] hen money or other consideration for the airing of program material has been received by or promised to a station, its employees or others, the station must broadcast full disclosure of that fact at the time of the airing of the material, and identify who provided or promised to provide the consideration. This requirement is grounded in the principle that members of the public should know who is trying to persuade them with the programming being aired. ${ }^{62}$

Sponsorships include such items as featuring products within the content of an episode. ${ }^{63}$ It also covers payment to air segments on television shows, infomercials, and other paid time. ${ }^{64}$ It does not, however, include the commercials that interrupt general programming. ${ }^{65}$

Even these requirements are rather minimal in effect. The disclosure requires little more than including a phrase "promotional consideration paid by" or "products provided by" placed in hurried end credits of a television episode.

Radio stations have an additional obligation to report any payments to employees to discourage payola - the practice of bribing DJs and programmers to promote certain acts or content. Under the law, station employees must disclose "any money, service or other valuable consideration for the broadcast of any matter over such station" to the station. ${ }^{66}$ Violation of the payola disclosure can result in a one-year jail sentence and $\$ 10,000$ fine.$^{67}$ Again, this is a rather minimal obligation to stop bribery and programming fraud, issues well within a regulatory police power.

${ }^{60}$ See Telecommunications Act of 1996, Pub. L. No. 104-104, 110 Stat. 56 (codified as amended in scattered sections of 47 U.S.C.).

${ }^{61}$ See 47 U.S.C. $\$ 317$ (2006); 47 C.F.R. $\$ 73.1212$ (2011).

${ }^{62}$ The Media Bureau, Fed. Commc'n COMm'n, The Public and BroadCasting: How to Get THE MOST SERvice From Your LoCal Station 22 (2008).

${ }^{63}$ See Joe Flint, FCC's Rules on Product Placement Disclosure, In Case You're Wondering, L.A. TIMES BLOG (Apr. 1, 2010, 6:36 PM), http://latimesblogs .latimes.com/entertainmentnewsbuzz/2010/04/product-placement-fcc-modern-family.html (noting use of iPad as promotional device in episode of Modern Family disclosed in credits as "products provided by Apple").

${ }_{64}$ Richard Kielbowicz \& Linda Lawson, Unmasking Hidden Commercials in Broadcasting: Origins of the Sponsorship Identification Regulations, 1927-1963, 56 FED. CoMM. L.J. 329, 331-32 (2004).

${ }^{65} \mathrm{Id}$. at $331 \mathrm{n} .5$ ("No other provision of broadcast law through the time studied here dealt directly with commercial advertising.").

${ }^{66} 47$ U.S.C. $\S 508(2006)$.

${ }^{67} \mathrm{Id} . \S 508(\mathrm{~g})$. 
The FCC also bans one category of products-tobacco. ${ }^{68}$ "Federal law prohibits the airing of advertising for cigarettes, little cigars, smokeless tobacco, and chewing tobacco on radio, TV, or any other medium of electronic communication under the FCC's jurisdiction." 69 The regulation, however, does not reside at the FCC and instead places this regulatory authority with the FTC and Food and Drug Administration (FDA). ${ }^{70}$

Children's television has more significant limitations. ${ }^{71}$ For example, "during the broadcast of TV programs aimed at children 12 and under, advertising may not exceed 10.5 minutes an hour on weekends and 12 minutes an hour on weekdays., ${ }^{, 72}$ Relying on the much-maligned scarcity doctrine of Red Lion Broadcasting Co. $v$. $F C C,{ }^{73}$ the $\mathrm{FCC}$ asserts jurisdiction to regulate the content of children's television as well as the ratio of advertising to content. ${ }^{74}$ Interestingly, this rather explicit regulation of content has not been met with constitutional scrutiny ${ }^{75}$ Alternatively, former FCC Chief Economist Thomas Hazlett and others suggest "broadcasters' acquiescence and willingness to support the 1997 [Children's Television Act] rules were in exchange for the free digital spectrum they were given in the late 1990s." ${ }^{.76}$

These various media regulations are all impingements on the free speech rights of the broadcasters. But they have withstood industry challenge or constitutional scrutiny because they tend to limit specific conduct that is within the government's power to regulate, rather than directly limiting the rights of speakers. This points the way forward for appropriate regulation of video games, both by the government as regulator and through state laws protecting the publicity rights of their citizens.

${ }^{68} 15$ U.S.C. $\S 1335$ (2006) (ban effective beginning Jan. 1, 1971).

${ }^{69}$ THE MEDIA BUREAU, supra note 62 , at 23 . Cigarette and cigar advertising has been a point of significant political action and tension. See, e.g., Family Smoking Prevention and Tobacco Control Act, 21 U.S.C. $\$ \S 387-387$ u (Supp. 2011); FDA v. Brown \& Williamson Tobacco Corp., 529 U.S. 120 (2000) (5-4 decision). The constitutionality of the recently passed provision is beyond the scope of this Article.

${ }_{70} 21$ U.S.C. $\$ 387 \mathrm{n}$ (Supp. 2011 ).

71 See Adam Candeub, Creating a More Child-Friendly Broadcast Media, 2005 MICH. ST. L. REV. 911, 915-16.

72 The Media BuREAU, supra note 62, at 18; see 47 U.S.C. $\S 303 \mathrm{a}(\mathrm{b})$ (2006); 47 C.F.R. $\$ 73.670(2011)$. frequencies).

${ }_{73} 395$ U.S. $367,396-400$ (1969) (justifying regulation based on scarcity of

${ }^{74}$ See Policies \& Rules Concerning Children's Television Programming, Revision of Programming Policies for Television Broad. Stations, 11 FCC Rcd. 10,660, 10,728-33 (1996).

${ }^{75}$ Candeub, supra note 71 , at 919.

${ }^{76}$ Id. at 918 (citing Thomas W. Hazlett, Prime Time: Clinton's Do-Bad TV Policy, REASON, Oct. 1996, at 66). 


\section{THE AWKWARD RELATIONSHIP BETWEEN ONLINE PUBLICITY RIGHTS AND FREE SPEECH}

In contrast to the incremental nature of implementation for the FTC Endorsement Guidelines, the recognition of individuals' publicity rights and the limitations of those rights in the new media of video games, virtual worlds, and online media has been a headlong and confusing descent. A review of the California approach to balancing the state's interest in protecting publicity rights with the court's duty to uphold free speech rights will highlight the need for an alternative formulation of state publicity rights.

In two California Supreme Court decisions, a new common law doctrine was established to separate a celebrity's rights of publicity from the free speech rights of the artist. $^{77}$ In Comedy III Productions, Inc. v. Gary Saderup, Inc. ${ }^{78}$ the California Supreme Court revised its test for publicity rights in the context of commercial speech. The work in question-a Gary Saderup drawing of the Three Stooges-was sold on T-shirts. ${ }^{79}$ The California Supreme Court made the threshold determination that "T-shirts at issue in [the] case did not constitute an advertisement, endorsement, or sponsorship of any product." concluded that the sale of the T-shirts "does not concern commercial speech. As the trial court found, Saderup's portraits of the Three Stooges are expressive works and not an advertisement for or endorsement of a product." $" 81$

Being expressive, of course, does not correlate one way or the other with proposing a commercial transaction. ${ }^{82}$ T-shirts are precisely the type of merchandise that celebrities market. ${ }^{83}$ They can also communicate a message. ${ }^{84}$ As a result, the better approach to these questions of mixed merchandise should

${ }^{77}$ Winter v. DC Comics, 69 P.3d 473, 477-79 (Cal. 2003) (holding use of musician brothers Johnny and Edgar Winter in comic books is transformative and protected by First Amendment); Comedy III Prods., Inc.,v. Gary Saderup, Inc., 21 P.3d 797, 811 (Cal. 2001) (holding drawing of Three Stooges sold commercially on T-shirts not transformative).

${ }^{78} 21$ P.3d at 797.

${ }^{79} \mathrm{Id}$. at 800 ("Saderup is an artist with over 25 years' experience in making charcoal drawings of celebrities. These drawings are used to create lithographic and silkscreen masters, which in turn are used to produce multiple reproductions in the form, respéctively, of lithographic prints and silkscreened images on T-shirts. Saderup creates the original drawings and is actively involved in the ensuing lithographic and silkscreening processes.").

${ }^{80}$ Id. at 801.

${ }^{81} \mathrm{Id}$. at 802 .

${ }^{82}$ See Bleistein v. Donaldson Lithographing Co., 188 U.S. 239, 250 (1903) (holding designs on circus poster sufficiently artistic and expressive to warrant copyright protection).

${ }^{83}$ See, e.g., Harley-Davidson, Inc. v. Morris, 19 F.3d 142, 149 (3d Cir. 1994) (barring sales of unauthorized Harley-Davidson T-shirts and finding seller in contempt from failing to stop all sales); Boston Athletic Ass'n v. Sullivan, 867 F.2d 22, 33 (1st Cir. 1989) (issuing injunction against unauthorized shirts with "Boston Marathon" slogan).

${ }^{84}$ United States v. O’Brien, 391 U.S. 367, 377 (1968). 
consider whether the communication is primarily a commercial one. The opinion acknowledged this as well when it found that "[b]y producing and selling such lithographs and T-shirts, Saderup thus used the likeness of [t]he Three Stooges on ... products, merchandise, or goods within the meaning of the statute." ${ }^{, 85}$

As a result, the California Supreme Court approached the case as noncommercial speech that could nonetheless be prohibited speech. It determined that while there is a tension with the First Amendment, the statute could nonetheless be upheld, consistent with the First Amendment based on an analysis that balances the interests of the speaker with the interests of the publicity rights holder ${ }^{86}$ It does this by adapting a portion of the copyright fair-use test as interpreted by the U.S. Supreme Court. ${ }^{87}$

This inquiry into whether a work is "transformative" appears to us to be necessarily at the heart of any judicial attempt to square the right of publicity with the First Amendment. ... [B]oth the First Amendment and copyright law have a common goal of encouragement of free expression and creativity, the former by protecting such expression from government interference, the latter by protecting the creative fruits of intellectual and artistic labor. ${ }^{88}$

The statement regarding the First Amendment and copyright is certainly accurate. In assuming, however, that by borrowing a single factor from the fair use analysis of copyright, the appropriate balancing could be achieved, the Comedy III court may have oversimplified the task. This may be evident by the development of the test in subsequent applications. In applying the Comedy III test in Winter v. $D C$ Comics ${ }^{89}$ the California Supreme Court explained the test as follows:

We developed a test to determine whether a work merely appropriates a celebrity's economic value, and thus is not entitled to First Amendment protection, or has been transformed into a creative product that the First Amendment protects. The "inquiry is whether the celebrity likeness is one of the 'raw materials' from which an original work is synthesized, or whether the depiction or imitation of the celebrity is the very sum and substance of the work in question. We ask, in other words, whether a product containing a celebrity's likeness is so transformed that it has become primarily the defendant's own expression rather than the

\footnotetext{
${ }^{85}$ Comedy III, 21 P.3d at 802 (internal quotation marks omitted).

${ }^{86} O^{\prime}$ Brien, 391 U.S. at 404-05.

87 Campbell v. Acuff-Rose Music, Inc., 510 U.S. 569, 579 (1994) (applying transformative test to fair use of parody in song lyrics).

${ }^{88}$ Comedy $I I I, 21$ P.3d at 808 .

${ }^{89} 69$ P.3d 473, 477 (Cal. 2003).
} 
celebrity's likeness. And when we use the word 'expression,' we mean expression of something other than the likeness of the celebrity." 90

As the test evolved in Winter, the emphasis shifted to a focus on economic versus artistic exploitation. Unlike the discussions in Virginia State Board of Pharmacy v. Citizens Consumer Council ${ }^{91}$ and Central Hudson, however, the two California decisions make little distinction between the artistry necessary to create a $\mathrm{T}$-shirt and the artistry necessary to create a communicative work. Although drawing on the transformative test from copyright law, ${ }^{92}$ the decisions do not reference distinctions for the use of publicity rights for the sale of commercial articles that rest at the heart of publicity rights law.

California's publicity rights statute requires that the use of the right be used "on or in products, merchandise, or goods, or for purposes of advertising or selling, or soliciting purchases of, products, merchandise, goods or services, without such person's prior consent." California common law, though complementing the statutory right, had not been applied to non-commercial interests. California's common law, the Comedy III court explains, relies on Dean William Prosser's influential article on privacy, separating common law rights of publicity from the other three types of torts enumerated by Prosser's analysis. ${ }^{94}$

It is instructive that Prosser's article discusses Donahue v. Warner Bros. Pictures, Inc. ${ }^{95}$ - a case decided the same year motion pictures were recognized to have First Amendment protection. Prosser notes approvingly of the state court ${ }^{96}$

${ }^{90}$ Winter v. DC Comics, 69 P.3d 473, 477 (Cal. 2003) (quoting Comedy III, 21 P.3d at 797).

91 425 U.S. 748 (1976).

${ }^{92}$ Comedy III, 21 P.3d at 808 ("Although such transformative use is not absolutely necessary for a finding of fair use, the goal of copyright, to promote science and the arts, is generally furthered by the creation of transformative works." (citations omitted) (quoting Campbell, 510 U.S. at 579)).

${ }^{93}$ CAL. Civ. Code $§ 3344$ (a) (West 1997).

${ }^{94}$ Comedy III, 21 P.3d at 799 (citing Lugosi v. Universal Pictures, 603 P.2d 425 (Cal. 1979)); see id. at 799 n.2; William L. Prosser, Privacy, 48 CAL. L. REV. 383, 389 (1960).

The law of privacy comprises four distinct kinds of invasion of four different interests of the plaintiff, which are tied together by the common name, but otherwise have almost nothing in common except that each represents an interference with the right of the plaintiff in the phrase coined by Judge Cooley, "to be let alone."

Prosser, supra, at 389 (quoting ThOMAS M. COOLEY, A Treatise ON THE LAW OF TORTS 29 ( 2 d ed. 1888)).

${ }^{95} 194$ F.2d 6 (10th Cir. 1952).

96 Donahue v. Warner Bros. Pictures Distrib. Corp., 272 P.2d 177 (Utah 1954) (finding right of privacy statute does not apply to semifictional motion picture of deceased celebrity's life). 
decision that nullified an earlier federal decision ${ }^{97}$ granting publicity rights to a deceased celebrity in a film that was partly fictional. ${ }^{98} \mathrm{He}$ recognizes the rights of publicity first described by Samuel Warren and Justice Louis Brandeis in their seminal article on privacy as requiring the sale or advertising of goods and services to invoke the right. ${ }^{99}$

Prosser was not a fan of publicity rights. Nonetheless, he acknowledged their role within the quartet of rights first identified by Warren and Brandeis. ${ }^{100} \mathrm{He}$ acquiesced:

[T]here are a great many decisions in which the plaintiff has recovered when his name or picture, or other likeness, has been used without his consent to advertise the defendant's product, or to accompany an article sold, to add luster to the name of a corporation, or for other business purposes. ${ }^{101}$

Only when publicity rights were associated with the sale or advertising of goods or services could the right properly be actionable, according to Prosser as well as Warren and Brandeis.

There have been a number of decisions that have blurred publicity with false light privacy or extended the doctrine's reach into protected speech, ${ }^{102}$ but these decisions are thankfully rather few and wholly inconsistent with the Supreme Court's First Amendment jurisprudence. An example of this can be found in the Missouri Supreme Court decision of Doe v. TCI Cablevision. ${ }^{103}$

${ }^{97}$ Donahue, 194 F.2d at 6.
${ }_{98}$ Prosser describes the inconsistency as follows:

In Donahue v. Warner Bros. Pictures, 194 F.2d 6 (10th Cir. 1952), it was held that a motion picture, based upon the life of a deceased celebrity but partly fictional, and using his name, came within the Utah statute. But in Donahue v. Warner Bros. Pictures Distributing Corp., [272 P.2d 177 (Utah 1954), the state court rejected this decision, and indicated that the statute was to be limited to the use of name or likeness in advertising, or the sale of "some collateral commodity." The effect of this is to nullify the federal decision.

Prosser, supra note 94 , at 402 n.161.

${ }^{99}$ Prosser, supra note 94 , at 401-07.

${ }^{100}$ Id. at 383-85 (discussing Samuel Warren \& Louis Brandeis, The Right to Privacy, 4 HARV. L. REV. 193 (1890)).

${ }^{101} I d$. at 401-02 (citations omitted).

${ }^{102}$ See, e.g., Ali v. Playgirl, Inc., 447 F. Supp. 723, 727 (S.D.N.Y. 1978) (discussing the likelihood of right of privacy and right of publicity violations due to defendant's unauthorized printing of an offensive portrait of the plaintiff); Spahn v. Julian Messner, Inc., 221 N.E.2d 543, 545 (N.Y. 1966), vacated, 387 U.S. 239 (1967) (discussing the difference between free speech protection for factual reporting and unprotected fictitious reporting as an exploitation of the plaintiff's personality).

${ }^{103} 110$ S.W.3d 363 (Mo. 2003). 
The Missouri Supreme Court framed the elements for right of publicity as follows: "(1) That defendant used plaintiff's name as a symbol of his identity (2) without consent (3) and with the intent to obtain a commercial advantage."104 By using the phrase "commercial advantage," the Missouri Supreme Court includes First Amendment protected content that relies on the goodwill of the individuals in the content for the sale of the publication. The decision recognizes the problem of this element but tries to separate out protected content from unfair commercial conduct:

By requiring that the jury find only that respondents "derived advantage from the use or publication of plaintiff's name," as opposed to a finding that respondents used plaintiff's name "with the intent to derive" or "for the purpose of deriving" an advantage, the jury was allowed to render a verdict that could have been based on the mere incidental result of the use rather than the intentional result. ${ }^{105}$

One can hardly doubt that the publishers of Sports Illustrated intend to take commercial advantage of the athletes featured in their news coverage, that a biographer selects her targets based not only on their newsworthiness but also on their popularity, and that a newspaper covers popular subjects not only when the subjects' popularity is "incidental." As the U.S. Supreme Court explained in New York Times Co. v. Sullivan, ${ }^{106}$ "That the Times was paid for publishing the advertisement is as immaterial in this connection as is the fact that newspapers and books are sold." 107

Newspapers need not be nonprofit to obtain the protection of the First Amendment and neither should comic books or other media. In all likelihood, an intent-based test reflects viewpoint restriction and is therefore prohibited under the First Amendment. As repeatedly noted by the U.S. Supreme Court, the threshold issue is whether the speech is "speech proposing a commercial transaction." 108 The sale of the comic book-like the sale of the newspaper-cannot satisfy the commercial transaction requirement. The test is not whether the objectionable speech proposes its own sale but whether the objectionable speech proposes the sale of some good or service. ${ }^{109}$ In the former, the speech must meet the standards
${ }^{104} \mathrm{Id}$. at 369 .
${ }^{105} \mathrm{Id}$. at 375 .
106 376 U.S. 254 (1964).
${ }^{107} \mathrm{Id}$. at 266.

${ }^{108}$ Cent. Hudson Gas \& Elec. Corp. v. Pub. Serv. Comm'n, 447 U.S. 557, 562 (1980); Ohralik v. Ohio State Bar Ass'n, 436 U.S. 447, 455-56 (1978).

${ }^{109}$ Rogers v. Grimaldi, 875 F.2d 994, 1004-05 (2d Cir. 1989); see Cent. Hudson, 447 U.S. at 562 (distinguishing between speech proposing commercial transactions, which are traditionally subject to regulations, and other types of speech); Ohralik, 436 U.S. at 455-57 (distinguishing between general legal services advertisements that are in print and an inperson offer of specific legal services to a particular client). 
of Sullivan and its progeny; in the latter, the speech must meet the standards of Central Hudson and the cases that follow.

In this context, the ability to regulate titles, advertising, and marketing for content-books, films, video games, etc.-also becomes better understood. An advertisement for a noncommercial use of speech is not a proposal for dialogue between the speakers and their audiences, nor is it a commercial transaction. If that proposal were fraudulent or unrelated to the speech being offered, then like knowingly false speech in the defamation setting, it would have no protection. ${ }^{110}$ So under both Sullivan and Central Hudson, such speech could be regulated. As demonstrated in Rogers v. Grimaldi, ${ }^{111}$ an unfair competition approach serves this purpose well by providing full and robust accommodation for matters of public interest and types of speech contemplated by copyright and trademark fair use. ${ }^{112}$

Assuming then that courts apply a constitutionally valid version of the publicity rights analysis, they must address each of the elements of the tort and pay particular attention to the constraint that such regulation of speech is part of the interest in regulating commerce. In the case of Comedy III, for example, the goods were T-shirts. The outcome was wholly consistent with the common law approach of Prosser, though the opinion arguably gave too much credence to the artist who extracts the publicity rights of a celebrity to sell a product.

Integrating the commercial purpose test with the copyright fair-use test provides a road map for the category of communicative products such as T-shirts, mugs and collectibles. The actual first prong of the fair-use test asks what is "the purpose and character of the use, including whether such use is of a commercial nature or is for nonprofit educational purposes." 113

This aspect of copyright law's first fair use factor invites a review of the purpose for the exploitation of the publicity right. Given that T-shirts play an important communicative role in society, had this factor been applied in Comedy III, this factor would tip the scales toward a finding of fair use for the defendant.

${ }^{110}$ See Cent. Hudson, 447 U.S. at 562-64 (discussing how commercial speech may be regulated when it fails to accurately inform the public and is more likely to deceive than to inform, or is related to illegal activity); Ohralik, 436 U.S. at 461-62 (finding a compelling interest in preventing fraud, undue influence, overreaching, and other forms of misconduct in solicitation).

${ }^{111}$ Rogers, 875 F.2d at 1000 ("Where a title with at least some artistic relevance to the work is not explicitly misleading as to the content of the work, it is not false advertising under the Lanham Act."); see also Estate of Hemingway v. Random House, Inc., 244 N.E.2d 250, 256 (N.Y. 1968) (holding that the estate of Ernest Hemingway had no cause of action for "palming off" or "unfair competition" against author of biographical memoir entitled Papa Hemingway).

112 See Parks v. LaFace Records, 329 F.3d 437, 448 (6th Cir. 2003); Mattel, Inc. v. MCA Records, Inc., 296 F.3d 894, 902 (9th Cir. 2002); Westchester Media v. PRL USA Holdings, Inc., 214 F.3d 658, 664-65 (5th Cir. 2000); Seale v. Gramercy Pictures, 949 F. Supp. 331, 339 (E.D. Pa. 1996).

11317 U.S.C. $\$ 107(1)(2006)$. 
At the same time, wide distribution of thousands of shirts would suggest primarily a commercial enterprise and diminish the likelihood of fair use.

More importantly, if the use in question is not to propose a commercial transaction, the fair-use test is not triggered, because the prima facie case is not met. But even if there is some commercial use, if the purpose of the commercial transaction also has a communicative purpose, then fair use might be applicable. As with copyright, this will in turn invite an analysis of the transformative nature of the use and a balance of the rights between the parties. ${ }^{114}$

The Third Circuit approached this question from the perspective of Supreme Court commercial speech regulation. In Facenda v. N.F.L. Films, Inc. ${ }^{115}$ the Third Circuit addressed the commercial or communicative nature of a twenty-two minute video aired on NFL Network. ${ }^{116}$ The Facenda court applied a three-factor test "to consider in deciding whether speech is commercial: (1) is the speech an advertisement; (2) does the speech refer to a specific product or service; and (3) does the speaker have an economic motivation for the speech." ${ }^{117}$ In Facenda, neither the length of the broadcast nor its distribution method on the NFL cable television network were sufficient to overcome the application of the test to "The Making of Madden NFL 06." The special was likely an infomercial created, designed, and aired to spur sales on the opening week of sales for the Madden 06 video game. ${ }^{118}$ The Supreme Court's test for commercial speech, as applied by the Facenda court, fully complements the first prong of the fair use analysis focusing on commercial activity. As used in this manner, the commercial factor provides an essential tool for extricating courts from the inappropriate position of determining when speech is worthy of protection or when speakers are sufficiently transformative - or artistic - as to be granted additional constitutional protections.

Although the California Supreme Court did not feel the other fair use factors in the test were of assistance, the copyright fair-use test provides for a robust body of law and may prove instructive as publicity rights laws develop. The fourth

${ }^{114}$ See Campbell v. Acuff-Rose Music, Inc., 510 U.S. 569, 578-79 (1994).

115542 F.3d 1007, 1011-12 (3d Cir. 2008).

116 Id. at 1012 ("In 2005, NFL Films produced 'The Making of Madden NFL 06' about the soon-to-be released annual update of the video game that simulates NFL games. This production is 22 minutes long and was shown on the NFL Network eight times in a three-day span leading up to the release of the video game to retail stores.").

${ }^{117}$ Id. at 1017 (quoting U.S. Healthcare, Inc. v. Blue Cross of Greater Phila., 898 F.2d 914, 933 (3d Cir. 1990)); see also Bolger v. Youngs Drug Prods. Corp., 463 U.S. 60, 66-67 (1983) (identifying each of the three factors that indicate commercial speech as "speech which does no more than propose a commercial transaction," speech in the form of advertisements, and speech by speakers with "an economic motivation." (citations omitted) (internal quotations marks omitted)).

${ }^{118}$ Facenda, 542 F.3d at 1017-18 ("While it does not advertise the game's price, the program did feature a clock at its ending that displayed the number of days until the video game's release for sale... . The second factor is easily satisfied because the program's sole subject is Madden NFL 06. . . Moreover, the video game's general promotion of NFLbranded football provides an additional indirect financial motivation. In this context, we deem 'The Making of Madden NFL 06' to be commercial speech.”). 
copyright factor, which looks to the economic impact, might be very helpful in certain situations. ${ }^{119}$ As applied, the "concern is not whether the secondary use suppresses or even destroys the market for the original work or its potential derivatives, but whether the secondary use usurps or substitutes for the market of the original work." 120 Since the fourth factor helps determine whether the unauthorized user is trying to compete in the marketplace with the owner of the rights instead of using the content for comment, criticism, or other transformative uses, the test could often prove very helpful. ${ }^{121}$

A licensor may be very concerned about the damage caused to the celebrity's ability to voluntarily license her identity to a competing company or even an unrelated company, if thrust into a marketing campaign for a product without consent. More practically, however, the question provides a mirror to the first copyright factor by asking whether the market impact of this use is primarily commercial or primarily communicative. Is the impact of the use to sell goods rather than any communicative activity of promoting a point of view?

Perhaps points of view are sometimes displayed on the side of a toaster. One can imagine, for example, selling a line of pet toys prominently featuring the pictures of celebrities who advertise fur coats. The tags and products propose a commercial transaction, but the use is to criticize and comment on the celebrity rather than to trade on the celebrity's goodwill. ${ }^{122}$ The balancing nature of the fairuse test should be sufficiently flexible to take this into account.

The California Supreme Court short-circuited both the use in commerce factor and the copyright fair use analysis, distorting the appropriate test for review. Instead of applying either the trademark or full copyright analysis, the California Supreme Court transformed the test into a focus on the quality and effectiveness of the communication. "[W]hen an artist's skill and talent is manifestly subordinated to the overall goal of creating a conventional portrait of a celebrity so as to commercially exploit his or her fame, then the artist's right of free expression is outweighed by the right of publicity." ${ }^{123}$ An artist's right to speak should not be

${ }^{119}$ Comedy III Prods., Inc. v. Gary Saderup, Inc., 21 P.3d 797, 808 (Cal. 2001) (rejecting the factor as "circular").

${ }_{120}$ Castle Rock Entm't, Inc. v. Carol Publ'g Grp., 150 F.3d 132, 145 (2d Cir. 1998).

121 See Harper \& Row, Publishers, Inc. v. Nation Enters., 471 U.S. 539, 566 (1985) ("Finally, the [Copyright] Act focuses on 'the effect of the use upon the potential market for or value of the copyrighted work.' This last factor is undoubtedly the single most important element of fair use." (quoting 17 U.S.C. $\S 107$ (2006))).

${ }^{122}$ See 17 U.S.C. $\S 107$ ("[F]air use of a copyrighted work . . . for purposes such as criticism, comment, news reporting, teaching (including multiple copies for classroom use), scholarship, or research, is not an infringement of copyright.").

${ }^{123}$ Comedy III, 21 P.3d at 810; see also Roberta Rosenthal Kwall, The Right of Publicity v. the First Amendment: A Property and Liability Rule Analysis, 70 IND. L.J. 47, 49-52 (1994) (proposing a balancing approach between the right of publicity and First Amendment rights). 
measured by the artist's creativity. The notion of a court interpreting conventional instead of transformative art is itself repugnant to the First Amendment. ${ }^{124}$

As can be expected from a decision based on flawed analysis, the problem has only become worse. In a series of cases, celebrities and athletes have alleged the improper exploitation of their names and likenesses in videogames. In Kirby v. Sega of America, Inc. ${ }^{125}$ a 1990s musical artist and choreographer, Kierin Kirby, ${ }^{126}$ sued Sega for unauthorized depiction of her likeness and signature phrase "ooh la la." 127 The video game, Space Channel 5, featured a character somewhat similar to Kirby in costume and used the name Ulala. ${ }^{128}$ Although the factual assertions that the character was based upon Kirby were merely sufficient to create a question of material fact, the court instead found the First Amendment a complete defense to the cause of action for state publicity rights and federal Lanham Act ${ }^{129}$ claims under section 43(a) for unfair competition. ${ }^{130}$

Summarizing the developing state law of California regarding the tension between publicity rights and free speech, the Kirby court explained:

The [transformative] test simply requires the court to examine and compare the allegedly expressive work with the images of the plaintiff to discern if the defendant's work contributes significantly distinctive and expressive content; i.e., is "transformative." If distinctions exist, the First Amendment bars claims based on appropriation of the plaintiff's identity or likeness; if not, the claims are not barred. ${ }^{131}$

${ }^{124}$ The Supreme Court has long recognized that the law and its judiciary should not be in the business of making value judgments on the merits of a work. See Bleistein v. Donaldson Lithographing Co., 188 U.S. 239, 250-51 (1903) ("If there is a restriction it is not to be found in the limited pretensions of these particular works. The least pretentious picture has more originality than in the directories and the like, which may be copyrighted. ... The antithesis to 'illustrations or works connected with the fine arts' is not works of little merit or of humble degree, or illustrations addressed to the less educated classes.").

12550 Cal. Rptr. 3d 607 (Ct. App. 2006).

${ }^{126} I d$. at 609 ('Kirby, professionally known as 'Lady Miss Kier,' 'Miss Kier' or 'Lady Kier' (hereafter, Kirby) was the lead singer of a retro-funk-dance musical group known as 'Deee-Lite' which was popular in the early 1990's. Deee-Lite made five albums which were distributed and sold throughout the world. The band was best known for its song 'Groove is in the Heart' from its first album released in 1990. The song's music video, which received extensive airplay on MTV, features band members clad in 'funky retro outfits, vivid graphics, groovy dance moves, a futuristic setting and an overall party feel.' In addition to being a musician, Kirby is a dancer, artist, choreographer and fashion designer. Kirby insists that, as 'Lady Kier,' she developed a 'specific, distinctive . . look,' of a "fashionable, provocative, and funky diva-like artistic character." (alteration in original)).

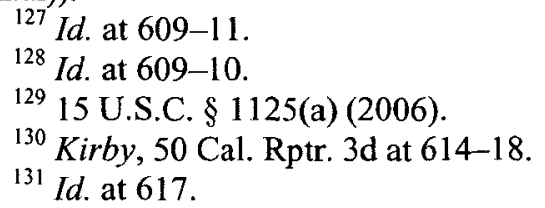


This summary of the Comedy III test bears only a passing relation to the original test and leaves the court to make value-based, content judgments. Following this decision, another California appellate court addressed whether a contractual agreement between the parties was to be interpreted using publicity rights. ${ }^{132}$ Instead of focusing on the terms of the express, written agreement, the court in No Doubt v. Activision Publishing, Inc. ${ }^{133}$ focused on the First Amendment rights of the parties as the basis for determining the rights under the agreement. ${ }^{134}$

The concurring opinion in No Doubt had a more reasonable approach: "I would conclude that, under the facts of this case, the contract between the parties precludes Activision's First Amendment claim, making it unnecessary to reach the 'transformative use' issue.",135

Courts continue to struggle with similar facts in the case of NCAA college athletes who are precluded from compensation by the amateur athletic rules and potentially by NCAA influence even after the players graduate from college. On identical facts, courts have made inconsistent determinations. ${ }^{136}$

Better than the tortured approach to tests of transformation or other judicial doctrines would be a return to the common law and statutory roots of publicity rights. To invoke the doctrine of publicity rights, the plaintiff must establish that the use of one's identity was in conjunction with the sale or advertising of a good or service (including Prosser's inclusion that advertising may be "to add luster to the name of a corporation, or for other business purposes"). ${ }^{13}$

Most media received complete First Amendment protection during the twentieth century. Now that video games have joined film and other media in receiving First Amendment protection, it is time to recognize that video games are immune from court-sanctioned forays into transformation, conventionality, or other value-laden judgments. ${ }^{138}$

132 No Doubt v. Activision Publ'g, Inc., 122 Cal. Rptr. 3d 397, 400-01 (Ct. App. 2011)

133122 Cal. Rptr. 3d at 397.

134 Id. at 410-12; see also Hilton v. Hallmark Cards, 599 F.3d 894, 912 (9th Cir. 2010) (finding liability when Paris Hilton's image depicted in similar cut-and-paste usage in a greeting card-a form considered more a product than a communicative medium); Hoffman v. Capital Cities/ABC, Inc., 255 F.3d 1180, 1180, 1189 (9th Cir. 2001) (finding no liability for using actor's face in magazine article featuring preview of designer dresses).

${ }^{135}$ No Doubt, 122 Cal. Rptr. 3d at 415 (Epstein, J., concurring).

${ }^{136}$ Compare Keller v. Elec. Arts, Inc., 94 U.S.P.Q.2d 1130, 1134-35,(N.D. Cal. 2010) (finding that lack of transformative nature of a game results in potential for liability), with Hart v. Elec. Arts, Inc., 808 F. Supp. 2d 757, 784 (D.N.J. 2011) (holding that the transformative nature of a game as a whole supports a finding of no liability).

${ }^{137}$ Prosser, supra note 94 , at 401-02.

${ }^{138}$ See Brown v. Entm't Merch. Ass'n., 131 S. Ct. 2729, 2733 (2011); cf. Bleistein v. Donaldson Lithographing Co., 188 U.S. 239, 250-53 (1903) (finding the new chromolithographs were sufficiently similar to pictorial illustrations to be protected under the current statute). 
In each of these video game cases, the depiction as an avatar or as part of the game play merely represents content without any proposed commercial activity. In each case there should be no First Amendment rights. But the absence of First Amendment rights does not negate the ability of parties to enter into contracts regarding participation of the celebrity, related rights of copyright and trademark, ancillary sales of goods, and a host of other terms that make such contracts fully valid and enforceable. ${ }^{139}$ The free speech protection is not the end of the analysis, only the beginning.

It should also be noted that a person's interest in controlling her identity in commercial ventures is not restricted to celebrities and professional athletes. The attractive, the unattractive, and the private individual may each have a strong desire not to be exploited without permission. Since the earliest of the successful common law right of publicity cases, Pavesich v. New England Life Insurance Co. ${ }^{140}$ courts did not require that the person photographed and used in an advertisement without permission be a famous person. ${ }^{141}$ Instead, the doctrine was specifically developed to protect the general public from the intrusion of a rather new, aggressive commercial advertising medium:

The knowledge that one's features and form are being used for such a purpose, and displayed in such places as such advertisements are often liable to be found, brings not only the person of an extremely sensitive nature, but even the individual of ordinary sensibility, to a realization that his liberty has been taken away from him; and, as long as the advertiser uses him for these purposes, he can not be otherwise than conscious of the fact that he is for the time being under the control of another, that he is no longer free, and that he is in reality a slave, without hope of freedom, held to service by a merciless master; and if a man of true instincts, or even of ordinary sensibilities, no one can be more conscious of his enthrallment than he is. ${ }^{142}$

The distinction does not directly change the standard for liability. There may be a significant difference in the context of fair use, however, since it is more likely that a person who is a public official or public figure will be the subject of comment and criticism from the public. ${ }^{143}$ To the extent such comment or criticism is done using commercial products and services, the nature of that comment and

${ }^{139}$ See Wood v. Lucy, Lady Duff-Gordon, 118 N.E. 214, 214 (N.Y. 1917) ("The law has outgrown its primitive stage of formalism when the precise word was the sovereign talisman, and every slip was fatal. It takes a broader view to-day. A promise may be lacking, and yet the whole writing may be 'instinct with an obligation,' imperfectly expressed. If that is so, there is a contract." (citations omitted)).

${ }^{140} 50$ S.E. $68(\mathrm{Ga} .1905)$.

${ }^{141} \mathrm{Id}$. at $79-80$.

${ }^{142} \mathrm{Id}$. at 80.

${ }^{143}$ See Comedy III Prods., Inc. v. Gary Saderup, Inc., 21 P.3d 797, 807-08 (Cal. 2001). 
criticism must be taken into account in determining whether the particular use constitutes a fair use. As a result, the private individual should receive greater rather than less protection under the doctrine.

The competing concerns of protecting the publicity rights of the individual while protecting the First Amendment rights of free speech can therefore be best met by first separating out commercial speech from noncommercial speech. Where speech is likely to propose a transaction, the courts then apply the full fair-use test to assure that comment, criticism, and transformative uses are permitted while the rights holder's interests are properly protected from unauthorized exploitation. To make this approach fit within the existing framework of the publicity rights doctrine, however, requires an additional update to the common law articulation of the rule regarding publicity rights.

\section{WITHIN THE FIRST AMENDMENT- \\ UPDATING THE COMMON LAW RULE FOR CONSTITUTIONAL SCRUTINY}

In light of the uncomfortable interpolation of publicity rights and free speech jurisprudence, the lessons of constitutional reassessment of defamation may be applied to publicity rights to achieve a prima facie case that meets established constitutional thresholds.

The Prosser (and Warren \& Brandeis) elements of the prima facie case for publicity rights infringement should be modified as follows:

(i) The plaintiff must establish that the name, picture, or other likeness (such as voice or signature) is "of or concerning the plaintiff";

(ii) The plaintiff must establish that use of the publicity rights were "proposing a commercial transaction" such as sale of goods or services or advertising those good or services; and

(iii) The plaintiff must establish that the use was without consent.

Even if using plaintiff's identity without consent does propose a commercial transaction, the defendant's use must be permitted if such use is a fair use, applying an equitable rule of reason after addressing all factors relevant to the court and considered material by the defendant.

The suggested test incorporates those tort concepts that have been constitutionalized in the defamation and commercial speech context. Regarding the first element of the test, the burden of proof for the prima facie case must be on the plaintiff. ${ }^{144}$ In controversial decisions such as White v. Samsung Electronics America, Inc. ${ }^{145}$ and Kirby, the underlying issue was less the law and more the reach of the law to the particular plaintiff. This does not mean that the depiction

${ }^{144}$ Masson v. New Yorker Magazine, Inc., 501 U.S. 496, 517 (1991) ("[T]he burden is upon petitioner to prove falsity.").

${ }^{145} 971$ F.2d 1395 (9th Cir. 1992). 
need necessarily be more literal, but it does shift the burden to the plaintiff to establish the connection. ${ }^{146}$

For the second element of the test, a clear adherence to the Central Hudson requirement for commercial purpose has been discussed earlier and need not be repeated here. Moreover, the three-factor test of Bolger v. Youngs Drug Products Corp. ${ }^{147}$ as applied in Facenda provides an excellent articulation of the approach. This element also helps to address some of the concerns raised by Judge Kozinski in his dissent in White. This element of the revised standard would rectify Judge Kozinksi's concerns regarding the harm of overprotecting intellectual property to restrain creativity in songs, novels, tabloids, and biographers. ${ }^{148}$ Similarly, the constitutionalization of fair use addresses the balancing questions raised by Judge Kozinski, enabling courts to promote public discourse without permitting free riders to exploit the goodwill of individuals to the detriment of their audience.

Regarding the third element of the test, the fair-use test should take into account the constitutional expansion that has already taken place. In Eldred $v$. Ashcroft ${ }^{149}$ the Court identified fair use as one of the constitutional safeguards for copyright, along with the idea-expression dichotomy that affords copyright protection only to expression, not the ideas underlying that expression. ${ }^{150}$ The test should also be applied properly. "The factors enumerated in the section are not meant to be exclusive: '[S]ince the doctrine is an equitable rule of reason, no generally applicable definition is possible, and each case raising the question must be decided on its own facts." "151 The refusal of a court to apply all four factors enumerated in the statute is somewhat problematic; a court's refusal to disqualify facts that will abrogate a defendant's constitutional rights is inconsistent with the purpose of fair use.

Fair use in the publicity rights context draws from trademark as well as copyright law. In applying the publicity fair use right, the role of nominative fair use must also be permitted. Nominative use applies "where the only word

${ }^{146}$ See id. at 1399 ("Viewed separately, the individual aspects of the advertisement in the present case say little. Viewed together, they leave little doubt about the celebrity the ad is meant to depict."); $c f$. White v. Samsung Elecs. Am., Inc., 989 F.2d 1512, 1513 (9th Cir. 1993) (Kozinski, J., dissenting) ("Overprotecting intellectual property is as harmful as underprotecting it. Creativity is impossible without a rich public domain. . . . Culture, like science and technology, grows by accretion, each new creator building on the works of those who came before. Overprotection stifles the very creative forces it's supposed to nurture.").

${ }^{147} 463$ U.S. 60 (1983).

${ }^{148}$ See White, 989 F.2d at 1513-14 (Kozinski, J., dissenting).

149537 U.S. $186(2003)$.

150 Id. at 219-20 ("[C]opyright law contains built-in First Amendment accommodations. First, it distinguishes between ideas and expression and makes only the latter eligible for copyright protection. ... Second, the 'fair use' defense allows the public to use not only facts and ideas contained in a copyrighted work, but also expression itself in certain circumstances." (citation omitted)).

151 Harper \& Row, Publishers, Inc. v. Nation Enters., 471 U.S. 539, 560 (1985) (quoting H.R. REP. NO. 94-1476, at 65 (1976)). 
reasonably available to describe a particular thing is pressed into service."152 As such, this use "lies outside the strictures of trademark law." ${ }^{153}$ Because it does not implicate the source-identification function that is the purpose of trademark, it does not constitute unfair competition. Such use is fair because it does not imply sponsorship or endorsement by the trademark holder.

Nominative fair use will be a valid defense if the commercial use was not furthered by the publicity rights but is instead factually necessary. For example, in distinguishing between two competing products, a retailer will lawfully be able to identify the inventor of one of the two products so as to avoid public confusion. This is factually necessary and a nominative use of the name that does not constitute an endorsement of the product. It instead merely constitutes a historical fact. If the use was highlighted, or done in a manner to suggest an endorsement, then the use would exceed the fair use afforded to the retailer. As the Supreme Court explained, "When the mark is used in a way that does not deceive the public we see no such sanctity in the word as to prevent its being used to tell the truth."154

These additional safeguards should put ample separation between the common law interest protected by publicity rights and the constitutional need for unencumbered free speech and robust debate. By updating the common law rule to integrate the various constitutional decisions that now frame publicity rights, the proposed articulation should provide clearer guidance regarding the law and its continued vitality. Such a restatement will not change the law, but it will assist in making the law coherent for all who try to apply it.

\section{BEYOND THE FIRST AMENDMENT- \\ REgulating THE COMMERCIAL ACTIVITIES Within TRADITIONAL MEDIA}

It is not sufficient to recognize that video games and virtual worlds are media entitled to First Amendment protection. As described with television and social media, all regulation does not disappear, nor is it barred by the First Amendment. As illustrated through the endorsement rules of the FTC, the sponsorship rules of the FCC, and specialized rules regarding children's television and tobacco, regulation and rights exist within the broadcast window and printed cover of television and magazines.

For purposes of establishing a property regime in media, the laws must meet intermediate scrutiny or address marketing that is misleading, deceptive, or

${ }^{152}$ New Kids on the Block v. News Am. Publ'n, Inc., 971 F.2d 302, 308 (9th Cir. 1992); accord Downing v. Abercrombie \& Fitch, 265 F.3d 994, 1009 (9th Cir. 2001).

${ }^{153}$ New Kids on the Block, 971 F.2d at 308 ("Because it does not implicate the sourceidentification function that is the purpose of trademark, it does not constitute unfair competition; such use is fair because it does not imply sponsorship or endorsement by the trademark holder."); see also Downing, 265 F.3d at 1008 (holding that models in Abercrombie \& Fitch advertisement had no rights that fell within subject matter of copyright for a misappropriation claim).

${ }_{154}$ Prestonettes, Inc. v. Coty, 264 U.S. 359, 368 (1924). 
aggressive. ${ }^{155}$ "A content-neutral regulation will be sustained under the First Amendment if it advances important governmental interests unrelated to the suppression of free speech and does not burden substantially more speech than necessary to further those interests." 156 The Supreme Court has repeatedly struggled with the application of this standard to various areas of speech. ${ }^{157}$ With regard to commercial speech, the better approach, of course, is to assure that any system addressing misleading, deceptive, or aggressive advertising still meets the test of intermediate scrutiny, as in United States $v$. Alvarez. ${ }^{158}$ As the Supreme Court has recently held, the government may not simply bar false speech. ${ }^{159}$ The plurality opinions in Alvarez highlight the challenge of crafting a coherent policy, yet Alvarez strongly suggests that even when addressing deceptive advertising, the speech has some constitutional protection, and as such the rules applied to such regulation must be narrowly tailored.

\section{A. Reviewing the Content}

Before applying this standard to video games and virtual worlds, it may be helpful to take a television example. During the 2008 presidential campaign, actress Tina Fey dominated the television airwaves with her portrayal of Alaskan governor and vice presidential candidate Sarah Palin. ${ }^{160}$ Nothing in the FCC regulations, FTC unfair trade practices, federal trademark laws, or state publicity rights would have afforded Governor Palin any cause of action against NBC or Ms. Fey for the satirical portrayal.

Had the portrayal of Palin, a public figure, met the actual malice standard of New York Times Co. v. Sullivan ${ }^{161}$ for self-identified satirical speech under Hustler Magazine, Inc. v. Falwell, ${ }^{162}$ then Palin could have brought an action for defamation. But as demonstrated in Hustler, this is an exceptionally high bar to meet. The Court envisioned that public officials and public figures have access to

${ }^{155} 44$ Liquormart, Inc. v. Rhode Island, 517 U.S. 484, 501 (1996) (plurality opinion).

${ }^{156}$ Turner II, 520 U.S. 180, 189 (1997).

${ }^{157}$ See id. at 186 ("[M]ust-carry provisions were content-neutral 'industry-specific antitrust and fair trade' legislation narrowly tailored to preserve local broadcasting ....").

158132 S. Ct. 2537 (2012); see id. at 2554.

${ }^{159}$ Id. at 2553 ("This Court has frequently said or implied that false factual statements enjoy little First Amendment protection. But these judicial statements cannot be read to mean 'no protection at all."' (citations omitted)) (Breyer J., concurring).

${ }^{160}$ See Julie Bosman; On 'SNL,' Fey as Palin, and Palin as Palin, N.Y. TIMES, Oct. 19, 2008, at A25 ("The appearance was Ms. Palin's effort to be good-natured after enduring weeks of mockery from the show, especially from Ms. Fey, whose winking, girlish, folksy impersonation of Ms. Palin has been called one of the most pitch-perfect in political satire.").

161376 U.S. 254, 279-80 (1964) (holding that actual malice requires proof that a defendant made a false statement with knowledge of the falsity or with reckless disregard for the truth).

${ }^{162} 485$ U.S. 46, 57 (1988) (applying the public figure standard for self-described parody to deny a celebrity's intentional infliction of emotional distress claim). 
the media in ways that afford more relevant recourse than defamation litigation. ${ }^{163}$ Governor Palin ${ }^{164}$ and former New York Governor David Paterson ${ }^{165}$ each responded to Saturday Night Live's political satire with appearances on the show to respond to the characterizations. In the case of Governor Paterson, his appearance was not shy-calling the writers and performers to task for the repeated juvenile humor focusing on the Governor's visual impairment as opposed to his politics or performance as a leader. ${ }^{166}$ In the context of defamation, the relationship between the First Amendment and the common law has been established-defamation law provides a direct constraint on speech. So for public officials and public figures, the law has a very high deference for the speaker and low protection for the subject of the objectionable speech.

But false speech is not entitled to unbridled protection. ${ }^{167}$ In the case of private figures, the interests of the speaker must be balanced more carefully with the interests of the person harmed by the falsity of the speech. ${ }^{168}$ Although the plaintiff must show proof of falsity, ${ }^{169}$ this is a far cry from immunity. Harmful, tortious false speech remains actionable.

\section{B. Distinguishing Commercial Conduct}

In the case of commercial speech, there is a similar gradation of protection. Extending the facts of the Saturday Night Live sketches to a more hypothetical situation, assume that NBC (licensor of Saturday Night Live) sold toasters or tables using tags featuring the image of either Sarah Palin or Tina Fey. Both would have a right of publicity that would require permission before their name or likeness was used to sell the commercial product. While the right implicates an interest of free speech, this is inherently a commercial transaction. The state's interest in

${ }^{163}$ N.Y. Times, 376 U.S. at 304-05 (Goldberg, J., concurring).

164 Bosman, supra note 160.

${ }^{165}$ Nicholas Confessore, Paterson Takes His Chances on 'Saturday Night Live,' N.Y. Times BLOG (Sept. 24, 2010, 11:13 AM), http://cityroom.blogs.nytimes.com/2010/09/24/ paterson-returns-to-saturday-night-live/.

${ }^{166}$ Id. ("'Saturday Night Live' has mercilessly mocked Gov. David A. Paterson's impaired vision and presented him as an improbably clumsy figure ... . The genial Mr. Paterson, in turn, has made it clear that he finds the parodies to be in poor taste, even for a comedy show.").

${ }^{167}$ Illinois ex rel. Madigan v. Telemarketing Assocs., Inc., 538 U.S. 600, 621 (2003) ("What the First Amendment and our case law emphatically do not require, however, is a blanket exemption from fraud liability for a fundraiser who intentionally misleads in calls for donations.").

168 Compare Phila. Newspapers, Inc. v. Hepps, 475 U.S. 767, 768-69 (1986) ("[W] here a newspaper publishes speech of public concern, a private-figure plaintiff cannot recover damages without also showing that the statements at issue are false."), with Gertz v. Robert Welch, Inc., 418 U.S. 323, 347 (1974) ("[S]o long as they do not impose liability without fault, the States may define for themselves the appropriate standard of liability for a publisher or broad-caster of defamatory falsehood injurious to a private individual.").

${ }^{169}$ Phila. Newspapers, 475 U.S. at 768-69. 
protecting its citizens' rights (whether as a property right or under a liability rule) is balanced against NBC's commercial transaction.

Moreover, the transaction is arguably misleading since the public could reasonably believe that the person identified has endorsed the product. ${ }^{170} \mathrm{Had}$ NBC used a photo of a celebrity that does not believe in the claims made by the product, the use of the celebrity's image would be in violation of the FTC Endorsement Guidelines. ${ }^{171}$ So the state and federal government both have an additional interest in sustaining claims against unauthorized endorsements so as to assure that actual endorsements are made within the regulatory scheme.

In the case of the television episode, the free speech rights are predominant; in the case of sale of goods, the interests of the endorser are predominant and benefit a broader commercial system of reliable, accurate endorsements. At the same time, however, these rights under both state statute and common law tend to invoke a number of copyright common law principles. For example, the common law right of publicity seems to incorporate the first sale or exhaustion doctrine such that no claim has been successful for the assertion of publicity rights in the resale of goods. ${ }^{172}$

The sale of a T-shirt continues to create a challenging, if not confounding example. Were a photograph on a T-shirt to accurately portray Tina Fey dressed as Sarah Palin, Tina Fey would likely have a publicity right in the commercial sale. ${ }^{173}$ Assuming the photograph was not significantly altered, the likeness would be as literal a translation one can make of a person's image. The much harder question is whether the photograph of Tina Fey's portrayal of Governor Palin would be sufficiently of or concerning Governor Palin to implicate her rights of publicity if reproduced and sold on T-shirts.

Like common law privacy and defamation, the "of or concerning test" must be the threshold question. ${ }^{174}$ One of the structural problems in Kirby was the very

${ }^{170}$ See Lanham Act, 15 U.S.C. § 1125 (2006); FTC Guides Concerning the Use of Endorsements and Testimonials in Advertising, 74 Fed. Reg. 53,124 (Oct. 15, 2009) (codified at 16 C.F.R. pt. 255).

${ }^{171}$ See 16 C.F.R $§ 255.1$.

172 See Allison v. Vintage Sports Plaques, 136 F.3d 1443, 1449 (11th Cir. 1998) ("[A]pplication of the first-sale doctrine to limit the right of publicity under Alabama law will maintain the appropriate balance between the rights of celebrities in their identities and the rights of the public to enjoy those identities . . .."); see also 17 U.S.C. $\S 109$ (Supp. 2011) (outlining copyright first-sale doctrine); Quanta Computer, Inc. v. LG Elecs., Inc., 553 U.S. 617, 621 (2008) (discussing the exhaustion part of patent jurisprudence going back over 150 years); Nannette Diacovo, Going Once, Going Twice, Sold: The First Sale Doctrine Defense in Right of Publicity Actions, 12 U. MIAMI ENT. \& SPORTS L. REV. 57, 89-91 (1995) (discussing applicability of doctrine and rationales for its incorporation).

${ }^{173}$ See Comedy III Prods. Inc. v. Gary Saderup, Inc., 21 P.3d 797, 808 (Cal. 2001).

${ }^{174}$ See, e.g., Cardone v. Empire Blue Cross \& Blue Shield, 884 F. Supp. 838, 847 (S.D.N.Y. 1995) ("In order to state a libel claim, plaintiffs must allege facts showing that the alleged defamatory statement was published 'of or concerning' them. Whether the complaint alleges facts sufficient to demonstrate a reasonable connection between the plaintiff and the alleged libel is a question for the court." (citations omitted)). 
weak evidence that the video game depicted the plaintiff. Rather than addressing this question separately, however, the court interpolated this factual issue into an analysis of the transformative nature of the game. ${ }^{175}$ The better approach and one more consonant with First Amendment jurisprudence is to require the plaintiff to establish that the depiction is of the plaintiff. ${ }^{176}$

The Prosser elements of the prima facie case remain the same: (i) name or picture or other likeness (such as voice or signature); (ii) has been used to advertise the defendant's product, to accompany an article sold, to add luster to the name of a corporation, or for other business purposes; (iii) without consent. ${ }^{177}$ Only if the elements of the prima facie case are met would the balancing be needed to address the speech interests of the unauthorized user. ${ }^{178}$

Like copyright, the lack of authorization is not an acknowledgement of infringement. ${ }^{179}$ The next step is to determine whether the fair-use test, when taken as a whole, results in infringing use. ${ }^{180}$ The transformative test focuses on the changes to image, ${ }^{181}$ but a useful reading of the fourth fair use factor might also be quite informative. The copyright language for the fourth factor is "(4) the effect of the use upon the potential market for or value of the copyrighted work." ${ }^{\prime 182}$ As discussed above in the context of Comedy III, the court asks whether the defendant's work is the type that could well displace the plaintiff's own work or whether it would tend to be a work that the plaintiff would not be interested in creating. ${ }^{183}$ "The fourth factor looks to adverse impact only by reason of usurpation of the demand for plaintiff's work through defendant's copying of [protectable] expression from such work." 184

${ }^{175}$ Kirby v. Sega of Am., Inc., 50 Cal. Rptr. 3d 607, 615-16 (Ct. App. 2006).

${ }^{176}$ See White v. Samsung Elecs. Am., Inc., 971 F.2d 1395, 1399 (9th Cir. 1992) ("The identities of the most popular celebrities are not only the most attractive for advertisers, but also the easiest to evoke without resorting to obvious means such as name, likeness, or voice."). As a practical matter, there appears to have been significant documentary evidence that the robot depicted in the Samsung ad was based on actual photographs of Ms. White, not just the depiction of a robot and the Wheel of Fortune letter board.

${ }_{177}$ See Prosser, supra note 94 , at 401-02.

${ }^{178}$ Cf. N.Y. Times Co. v. Sullivan, 376 U.S. 254, 266 (1964) (applying constitutional requirements only if the threshold common law tort of defamation is sufficiently pleaded).

${ }^{179}$ See 17 U.S.C. $§ 107$ (2006); Nihon Keizai Shimbun, Inc. v. Comline Bus. Data, Inc., 166 F.3d 65, 69-70 (2d Cir. 1999); Castle Rock Entm't, Inc. v. Carol Publ'g Grp., Inc., 150 F.3d 132, 137 (2d Cir. 1998); Fisher-Price, Inc. v. Well-Made Toy Mfg., 25 F.3d 119, 122-23 (2d Cir. 1994).

${ }^{180}$ See Harper \& Row, Publishers, Inc., v. Nation Enters., 471 U.S. 539, 560 (1985); Castle Rock Entm't, 150 F.3d at 146.

${ }^{181}$ Campbell v. Acuff-Rose Music, Inc., 510 U.S. 569, 579 (1994).

18217 U.S.C. $\$ 107(4)$.

${ }^{183}$ See supra notes 77-94 and accompanying text.

${ }^{184}$ SunTrust Bank v. Houghton Mifflin Co., 268 F.3d 1257, 1274 (11th Cir. 2001) (quoting 4 Melville B. Nimmer \& David Nimmer, Nimmer on COPYRight $\S$ 13.05[A][4] (1994)). 
In this light, the fourth factor allows broader fair use where there is market failure or the transaction costs are too high to develop a scheme for licensing, while encouraging licensing instead of self-help where such a system exists. The fourth factor emphasizes comment and criticism over emulation. So it is particularly useful for trinkets and collectibles, where the owner of the rights (either copyright or publicity right) would likely be in the market for flattering goods but would object to goods that created parody, satire, or criticism.

But unlike the decision in Winter, the test for the publicity rights cause of action is only reached when there is a good or service being marketed. ${ }^{185}$ In the case of the Saturday Night Live T-shirts, the suggested fourth factor would result in a photograph of Tina Fey on a T-shirt likely being subject to Ms. Fey's publicity rights. Similarly, a flattering photograph of Sarah Palin on a T-shirt would be subject to Governor Palin's publicity rights. But a T-shirt of Tina Fey in costume as Sarah Palin would be unlikely to trigger any publicity rights for Governor Palin. To the extent such an example captured the essence of the Saturday Night Live sketches, Tina Fey's publicity rights would likely survive in that T-shirt as well, but if the slogan or other context on the shirt were critical of the skits or Ms. Fey, then neither party would likely have publicity rights.

Courts must not apply these categorizations too mechanically. The fact that a speaker must pay for an advertisement to be heard does not transform that content into commercial speech, ${ }^{186}$ and courts must be rigorous to require that any regulated speech is "speech proposing a commercial transaction." 187

Of course there remains some ambiguity, and line drawing has always been endemic to cases balancing copyright or speaker's rights. But the number of ambiguous cases drops dramatically when speaker's rights are categorically protected unless a plaintiff can establish that the speaker is proposing commercial activity without authorization.

${ }^{185}$ Although the decision in Comedy III did not use the factor, it followed its logic, finding that the Three Stooges drawing was careful and exact, serving as an emulation usurping a marketing opportunity rather than a comment or criticism of the subject. See Comedy III Prods. Inc. v. Gary Saderup, Inc., 21 P.3d 797, 811 (Cal. 2001).

${ }^{186}$ See N.Y. Times Co. v. Sullivan, 376 U.S. 254, 266 (1964) ("The publication here was not a "commercial" advertisement. . . . It communicated information, expressed opinion, recited grievances, protested claimed abuses, and sought financial support on behalf of a movement whose existence and objectives are matters of the highest public interest and concern. That the Times was paid for publishing the advertisement is as immaterial in this connection as is the fact that newspapers and books are sold. . . [I]f the allegedly libelous statements would otherwise be constitutionally protected from the present judgment, they do not forfeit that protection because they were published in the form of a paid advertisement." (citations omitted)).

${ }^{187}$ Cent. Hudson Gas \& Elec. Corp. v. Pub. Serv. Comm'n, 447 U.S. 557, 562 (1980); see also Ohralik v. Ohio State Bar Ass'n, 436 U.S. 447, 455-56 (1978) (recognizing, for First Amendment protection purposes, a distinction between "speech proposing a commercial transaction, and other varieties of speech"). 


\section{Considerations for Commercial Conduct in the Media}

One last type of commercial conduct must be considered-commercial activity within the medium. As identified in the FCC and FTC regulations, speech in media sometimes gives way to commercial conduct transacted through the media. ${ }^{188}$ Congruent with longstanding First Amendment protections, traditional television, radio, newspaper, and magazine advertising is treated as commercial speech, allowing for government regulation and application of publicity rights enforcement. ${ }^{189}$

Focusing on the regulatory scheme of the FTC and FCC, one significant consideration is the need to assure that a person promoting a good or service is intentionally doing so and can meet the regulatory obligations to do so. ${ }^{190}$ For example, the regulation provides the following information:

Example 4: A well-known celebrity appears in an infomercial for an oven roasting bag that purportedly cooks every chicken perfectly in thirty minutes. During the shooting of the infomercial, the celebrity watches five attempts to cook chickens using the bag. In each attempt, the chicken is undercooked after thirty minutes and requires sixty minutes of cooking time. In the commercial, the celebrity places an uncooked chicken in the oven roasting bag and places the bag in one oven. He then takes a chicken roasting bag from a second oven, removes from the bag what appears to be a perfectly cooked chicken, tastes the chicken, and says that if you want perfect chicken every time, in just thirty minutes, this is the product you need. A significant percentage of consumers are likely to believe the celebrity's statements represent his own views even though he is reading from a script. The celebrity is subject to liability for his statement about the product. The advertiser is also liable for misrepresentations made through the endorsement. ${ }^{191}$

${ }^{188}$ See supra Part III.A-B.

189 See Abdul-Jabbar v. General Motors Corp., 85 F.3d 407, 416 (9th Cir. 1996) (use of athlete's name in voice-over for television commercial); Midler v. Ford Motor Co., 849 F.2d 460, 463 (9th. Cir. 1988) (television commercial); Motschenbacher v. R.J. Reynolds Tobacco Co., 498 F.2d 821, 825-27 (9th Cir. 1974) (television commercial); Allen v. Nat'l Video, Inc., 610 F. Supp. 612, 620-21 (S.D.N.Y 1985) (magazine advertisement); Grant v. Esquire, Inc., 367 F. Supp. 876, 880 (S.D.N.Y 1973) (magazine advertisement); Uproar Co. v. Nat'l Broad. Co., 8 F. Supp. 358, 360 (D. Mass. 1934) (radio); Rosenberg v. Lee's Carpet \& Furniture Warehouse Outlet, Inc., 363 N.Y.S.2d 231, 233 (Sup. Ct. 1974) (newspaper advertisement).

${ }^{190}$ See 16 C.F.R. $\$ 255.1$ (2012) (requiring that advertisers who continue to use endorsements reasonably believe the endorser still subscribes to the endorsement or uses the product).

${ }^{191} I d . \S 255.1$ ex. 4. 
In the case of the infomercial, the celebrity is likely to be fully aware of her participation. Change the facts slightly, however, and one can readily imagine an underhanded weight loss infomercial in which celebrities are shown in photographs of before and after shots, allegedly demonstrating the weight loss effected by the product being sold. Under the FTC Endorsement Guidelines, the celebrities so pictured would have an affirmative duty for statements made using their pictures if the person depicted did not actually use the product or lose the reported weight.

A much more difficult situation arises when weight-loss programs publish celebrity pictures or film clips without permission. For example, actress Jessica Alba recently brought an action against the makers of Belly Bandit for use of her name and image on its weight loss campaign. ${ }^{192}$ If the claim is accurate, such an unauthorized use reflects a commercial use of the celebrity's name and likeness without permission that has consistently resulted in an actionable claim.

In addition, as the FTC suggests, the public would consider the celebrity's participation an endorsement, but since the celebrity neither consented nor was consulted, there can be no veracity to the claim. The public is being misled. The advertiser would be liable to the FTC for an unfair trade practice, but given the limited resources available to the regulatory agency, it is important that the celebrities involved take personal action to protect their integrity and the integrity of the marketplace.

A variation of this scenario may be developing more commonly as commercial sponsorship has returned to television. While an actor portraying a character in a television episode is unlikely to need to satisfy the endorsement obligations, ${ }^{193}$ a celebrity appearing on a talk show, contest show, or reality television episode should be constrained by the FTC Endorsement Guidelines. The celebrity's use or promotion of a product would influence the public and therefore should be permitted only if honest and accurate. ${ }^{194}$ The FTC requires honesty from

${ }^{192}$ Lindsay Goldwert, Jessica Alba Sues Maker of Belly Bandit for \$1 Million; Alba Denies Endorsing Weight Loss Product, N.Y. DAlly NEWs (Oct. 12, 2011), http://articles.nydailynews.com/2011-10-12/entertainment/30291563_1_weight-lossproduct-website-weight-loss/.

${ }^{193}$ But a different result may occur if the performer is not informed of what has been created. See BowfINGER (Universal Studios 1999) (telling a fictional story of a desperate movie producer who attempts to slyly film a feature-length movie around an unsuspecting famous actor and a look-alike actor).

${ }^{194}$ See 16 C.F.R. $\S \S 255.0($ b), 255.1(a) (2012).

For purposes of this part, an endorsement means any advertising message (including verbal statements, demonstrations, or depictions of the name, signature, likeness or other identifying personal characteristics of an individual or the name or seal of an organization) that consumers are likely to believe reflects the opinions, beliefs, findings, or experiences of a party other than the sponsoring advertiser, even if the views expressed by that party are identical to those of the sponsoring advertiser. The party whose opinions, beliefs, findings, 
the endorser. ${ }^{195}$ The FCC complements this by requiring that the consideration be acknowledged in the credits. ${ }^{196}$ Together, the system reflects a desire to keep the existence of commercial content recognizable for the consumer.

Additional issues are arising with regard to embedded sponsorships in editorial content. In these situations, issues arising in media like television, motion pictures, and magazines may be better understood through the rules of video game advertising.

Rather than trying to treat video games and virtual worlds as conceptually separate from traditional media, a much better approach will be to import these existing expectations into the media activity. Of course, just as television, print, film, and newspapers may have some minor differences among the various media, the rules applying to new media must take those issues into account as well.

\section{BEYOND THE FIRST AMENDMENT-REGULATING COMMERCIAL ACTIVITIES

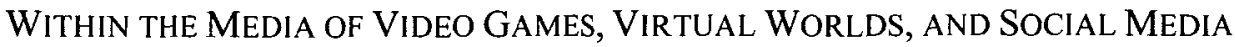

As demonstrated by the Supreme Court, video games, virtual worlds, and social media are constitutionally protected media that should be treated as much like traditional media as possible. Just as the Court pointed out that the risks of video games were in degree rather than kind, ${ }^{197}$ the approach of the Court to limit and frame regulation in the context of media generally rather than in relation to the particular technology will allow the technologies and doctrine to evolve more appropriately.

Interactive digital media-including, inter alia, video games, virtual worlds, websites, social media, and mobile applications - should be addressed distinctively only where particular technologies would otherwise create unintended outcomes. New technologies have been a part of the First Amendment jurisprudence throughout the past century, but "'the basic principles of freedom of speech and the press, like the First Amendment's command, do not.vary' when a new and different medium for communication appears." ${ }^{198}$ The sale of the games or the

or experience the message appears to reflect will be called the endorser and may be an individual, group, or institution.

Id. $\S 255.0$ (b). The audience will likely be able to separate out the beliefs of a character from the person portraying that character in fictional media, but the audience should be able to rely on the nonfictional nature of the other media to expect the person to mean what they present.

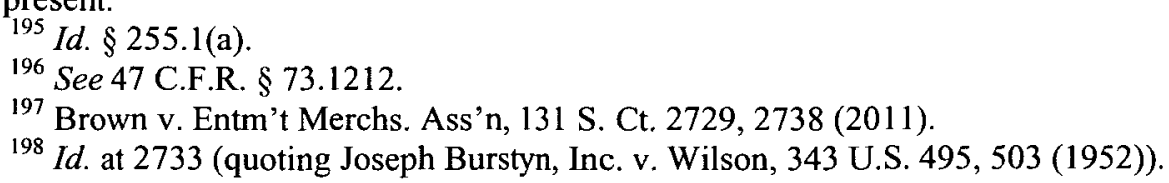


commercial nature of their play is irrelevant. It is no more relevant that video games are sold than that books and newspapers are sold. ${ }^{199}$

\section{A. No Licenses Are Required for Avatars}

The consequence of treating interactive digital media as traditional media necessitates treating those activities as wholly protected by the First Amendment. The use of an avatar in a video game is no different than Tina Fey's portrayal of Governor Palin: both are protected speech. The decision in Kirby was correct, not because the use was transformative, but because there is simply no right of publicity in the absence of speech proposing commercial conduct. ${ }^{200}$ In this regard, interactive digital media should be treated in the same manner as biographies, documentaries, gossip magazines, and the media that covers sports and entertainment.

The lack of a legal right will not lead to the wholesale unauthorized use of celebrities in video games for a few practical reasons. First, the laws of defamation also continue to apply in their traditional context so that knowingly false depictions will give rise to liability just as they would in film, theatre, and television. Secondly, the commercial importance of the celebrity depiction comes not only from participation in the content, but also importantly from active participation in marketing and promoting the content.

A third important factor is the access necessarily afforded to game makers so they are effective in creating high quality content. The rule described for video games is no different than the rule for narrative and documentary films. There is no requirement of obtaining the consent of a person depicted. But the need for access to private information, the assistance that can come from the person involved, and the assurances that the party is not collaborating with a direct competitor drive most professionals to seek licenses as a practical business requirement. ${ }^{201}$

Even if there is some expansion of the unauthorized use of avatars in video games and virtual worlds, there is simply no basis for distinguishing this

${ }^{199}$ See N.Y. Times Co. v. Sullivan, 376 U.S. 254, 266 (1964) (finding that it does not matter if publisher was paid to publish the material to determine whether the speech is considered commercial).

${ }^{200}$ See supra Part VI.A-B.

${ }^{201}$ This is why the litigation involving athletes includes student athletes. Even in the absence of any legal requirement, the game publishers would prefer license agreements, "official" products, and the goodwill of the players. It is the legal infirmity caused by the NCAA eligibility rules that interferes with the appropriate market forces and triggers the dispute. Cf. Hart v. Elec. Arts, Inc., 808 F. Supp. 2d 757, 784 (D.N.J. 2011 ) (finding game not transformative); Keller v. Elec. Arts, Inc., 94 U.S.P.Q.2d 1130, 1134-35 (N.D. Cal. 2010) (involving former college football player's allegation that Electronic Arts and the NCAA negotiated use of his likeness without his consent); In re NCAA Student-Athlete Name \& Likeness Licensing Litig., 2011-2 Trade Cas. (CCH) ๆ 77, 549 (N.D. Cal. 2011) (describing the "exceptionally close" and "unique relationship" Electronic Arts has with the NCAA). 
environment from the mainstream media. Gossip magazines exist solely on the basis of the unauthorized depiction of celebrities. Whether tolerated or despised, they represent protected speech that is part of the ecology of the celebrity. The existence of their counterparts in cyberspace may be bemoaned, but it cannot be denied.

\section{B. Commercial Conduct in Cyberspace Still Requires Consent, Disclosure, and Honesty}

A different outcome should occur if the use triggers a proposal for commercial conduct. The elements of the prima facie case remain the same: (i) name or picture or other likeness (such as voice or signature); (ii) has been used to advertise the defendant's product, to accompany an article sold, to add luster to the name of a corporation, or for other business purposes; (iii) without consent. ${ }^{202}$ The only difference from the common law tradition is the efficacy of an interactive medium.

Interactive digital media has two features that distinguish it from traditional media to a certain degree. First, through hyperlinks, QR codes, or other technologies, a vendor can link the identity of the endorsing party more directly with goods and services. With the click of a mouse or touch of a finger, a consumer can complete the purchase of an item displayed on the screen. In contrast, even an infomercial requires the consumer to dial a phone number and speak to a sales agent.

The efficiency of interactive digital media enhances the power of the publisher to propose-and consummate- the consumer transaction more readily, so the law should take into account this ease of commercial conduct. But this difference is based on technology, not medium. A newspaper presented on a computer or mobile device has the same efficiencies as a blog or video game. The newspaper's use of the technology to consummate sales of goods should be treated with no greater or lesser deference than that of the blogger or video game publisher.

Second, unlike with television and motion pictures, it remains technologically more difficult to embed a celebrity in interactive digital media content without the participation of that celebrity. A producer must instead use a look-alike to approximate a celebrity ${ }^{203}$ or digitally recreate a performance. ${ }^{204}$ The technique is popular in advertising ${ }^{205}$ but expensive for feature projects (for now). In media that

${ }^{202}$ Prosser, supra note 94, at 401-02.

${ }^{203}$ See Allen v. Nat'l Video, Inc., 610 F. Supp. 612, 623 (S.D.N.Y. 1985) (explaining that privacy law allows an actor to evoke certain aspects of another's personality as long as she does not represent herself as the other person).

204 See Robert Klara, I See Dead People, ADWEEK (March 14, 2011), http://www.adweek.com/news/advertising-branding/i-see-dead-people-126364/.

${ }^{205}$ See id. ("Licensing deals with actors, singers and other notables who've shuffled off this mortal coil generated $\$ 2.17$ billion last year-quite a paycheck for doing nothing.") 
is animated, however, no such barrier exists, so comic book authors have no particular barriers to access celebrity identities. ${ }^{206}$ Much of interactive digital media is animated to a greater or lesser degree, and therefore the need to personally involve a celebrity in the creation of content is simply not a production imperative. As a result, one of the key opportunities to arrange consent and to control the use of one's identity is missing from interactive digital media.

Neither of these differences is exceptional; they are just part of the continuum of media that ranges from highly literal to highly conceptual. In all media, however, there are implications regarding how consent is obtained and how the use of content or advertising is communicated to the endorser.

To better understand how the common law, statutory, and regulatory duties apply, a series of guidance hypotheticals based upon those of the FTC may prove the most helpful.

\section{Example 1:}

"A television advertisement for a particular brand of golf balls shows a prominent and well-recognized professional golfer practicing numerous drives off the tee. This would be an endorsement by the golfer even though she makes no verbal statement in the advertisement."207

As an endorsement, this is also a commercial use of the professional golfer's identity, requiring express permission.

If utilized in interactive digital media where the publisher of a video game was the golf ball manufacturer, predominantly using the game for the sale of its golf balls, that use would be a commercial use requiring express permission. The test would not be intent, but whether the publisher was gaining direct commercial advantage from the sales of the golf balls promoted by the game.

If used in interactive digital media, and the publisher of a video game was not the golf ball manufacturer but chose to name a brand of golf balls for verisimilitude, that use would not be a commercial use and would require no express permission. Since the publisher was not gaining any commercial advantage tied to the sales of the golf balls, it would not be proposing a commercial transaction.

Using the same facts as above, if the publisher allowed the consumer to click, touch, or otherwise interact with the golf balls, the publisher still would not be proposing a commercial transaction unless the publisher received direct or indirect compensation for the interactivity. For example, if the publisher received a portion of the proceeds from the sales of the golf balls or if the publisher received

${ }^{206}$ See, e.g., Winters v. D.C. Comics, 69 P.3d 473, 476 (Cal. 2003) (finding no liability for incorporating musicians into comic book characters); Doe v. McFarlane, 207 S.W.3d 52, 56 (Mo. Ct. App. 2006) (finding liability for incorporating hockey players into comic book characters).

${ }^{207} 16$ C.F.R. $\S 255.0(\mathrm{e})$ ex. $5(2012)$. 
compensation from the golf ball producer for providing the interactivity, only then would the publisher be engaging in a commercial transaction.

\section{Example 2:}

A film critic reviews a motion picture. ${ }^{208}$

The review is originally published in a newspaper-this does not require the publisher to obtain any rights of publicity for the critic (though the employment agreement may require the publisher to do so for other reasons).

The review is originally published on a website-this does not require the publisher to obtain any rights of publicity for the critic (though the employment agreement may require the publisher to do so for other reasons).

The interactive digital media version of the review includes links to the film's web page, to the film distributor, and to a listing of exhibitors. There is no direct or indirect payment from these parties to the publisher or reviewer, so there would be no proposal of a commercial transaction. In the same way, news stories that link to the home page or stock exchange listing of the companies mentioned in the story do not propose any commercial transaction and need no disclosures or permissions.

The interactive digital media version of the review includes links to the film's web page, to the film distributor, and to a listing of exhibitors paid for by the film producer. If the publisher and film review were to come to rely on the revenues of the film distributor, it would likely encourage more positive reviews. Such payments should require disclosure by the publisher and could rise to an endorsement if made to the reviewer directly or made a condition of employment by the publisher receiving compensation.

The review is accurately excerpted on an unrelated website or news aggregator service. This does not require the publisher or re-publisher to obtain any rights of publicity for the critic.

\section{Example 3:}

"A film critic's review of a movie is excerpted in an advertisement. When so used, the review meets the definition of an endorsement because it is viewed by readers as a statement of the critic's own opinions and not those of the film producer, distributor, or exhibitor."209

"Endorsements must reflect the honest opinions, findings, beliefs, or experience of the endorser. Furthermore, an endorsement may not convey any express or implied representation that would be deceptive if made directly by the advertiser."210

${ }^{208}$ See id. ex. 1.

${ }^{209} I d$. ("Any alteration in or quotation from the text of the review that does not fairly reflect its substance would be a violation of the standards set by this part because it would distort the endorser's opinion.”); see id. § 255.1(b).

${ }^{210} \mathrm{Id}$. $\S 255.1$ (a) (citation omitted). 
"When there exists a connection between the endorser and the seller of the advertised product that might materially affect the weight or credibility of the endorsement (i.e., the connection is not reasonably expected by the audience), such connection must be fully disclosed." 211

In the area of reviews, accurate reporting of such information has been treated as being available to the film producer, distributor, or exhibitor as implied consent or under a fair use analysis. ${ }^{212}$

In the absence of consent by a film critic or other content creator, the extent of the fair use of such unintended exploitation of the endorsement should be modest and take into account the forum in which the original content was presented. It is in the public's interest that positive statements about goods, services, or media not be commercially exploited for commercial gain because such use would chill comments about such products and could constitute a form of aggressive marketing that should be actionable. The next examples explore this challenge.

\section{Example 4:}

"A television advertisement for a housewares store features a wellknown female comedian and a well-known male baseball player engaging in light-hearted banter about products each one intends to purchase for the other. The comedian says that she will buy him a Brand $X$, portable, high-definition television so he can finally see the strike zone. He says that he will get her a Brand Y juicer so she can make juice with all the fruit and vegetables thrown at her during her performances. The comedian and baseball player are not likely to be deemed endorsers because consumers will likely realize that the individuals are not expressing their own views."213

The FTC guidance on this fact pattern seems inconsistent with the other guidance on celebrity endorsements and suggests that a comedian and athlete may misrepresent their personal preferences if it is sufficiently clear that they are appearing in an advertisement. It is difficult to think these participants in the advertisement are substantially different from the celebrity in the cooking show watching the undercooked chicken. ${ }^{214}$. The challenge here is that this is a "television advertisement" rather than an infomercial, so that the celebrity's

${ }^{211} I d . \S 255.5$.

${ }^{212}$ Cf. Consumers Union of U.S., Inc. v. New Regina Corp., 664 F. Supp. 753, 767 (S.D.N.Y. 1987) (finding no First Amendment violation for suppressing inaccurate advertisements); Mark S. Nadel, The Consumer Product Selection Process in an Internet Age: Obstacles to Maximum Effectiveness and Policy Options, 14 HARV. J.L. \& TECH. 183, 234-35 (2000) (arguing that information should be made available to anyone as a public good).

${ }^{213} 16$ C.F.R. $\$ 255.0$ (e) ex. 7 ; id. ex. 1 ("Any alteration in or quotation from the text of the review that does not fairly reflect its substance would be a violation of the standards set by this part because it would distort the endorser's opinion."); see id. § 255.1 (b).

${ }^{214} I d$. $\$ 255.1$ ex. 4; see supra text accompanying note 191. 
appearance in the ad suggests less honesty is required. ${ }^{215}$ Perhaps since, in this case, the description of the advertisement includes no claims about the products, the comedian's or athlete's participation would only be misleading if either party had actual knowledge of problems with the products or a personal dislike of the products which she continued to promote. In such a case, the continued participation in the advertisement might well violate the FTC Act notwithstanding the guidance. ${ }^{216}$

The better approach is to recognize that in a television ad, the format informs the public of the paid consideration. Everyone in an advertisement is presumed to have been paid. The duty of honesty should apply in every situation.

The appearance would certainly require express publicity rights, since this is the use of the comedian's and athlete's identity to sell goods.

\section{Example 5:}

A well-known comedian appears on a talk show following another guest who appeared promoting his diet book. The comedian commented "I'm going to run out and buy this" or similar language that garnered a positive response from the audience. The off-the-cuff remark would not be an endorsement in the absence of any prior consideration or relationship between the comedian and the book author or publisher. ${ }^{217}$

If the clip were to appear on a social media site, the presence in that format would not change the status of the comedian. The comedian would have no right of publicity to stop the posting of the clip to a social media site.

If the clip were posted to the publisher's website, such use would constitute a commercial use and would require that the comedian's permission be obtained. In such case, the comedian should only be able to provide such permission if she can satisfy the conditions as an endorser of the product. Such use would transform the clip into an endorsement of the product when used by the publisher or the author for marketing or promotion.

\section{Example 6:}

A video game incorporates accurate portrayals of musicians as part of the game play within the video game.

The game itself is not a commercial good requiring express permission for purposes of right of publicity, nor is it an endorsement of the songs performed. This result is not changed by the ability of the user of the game to alter the character or change the manner in which it is played.

${ }^{215}$ See id. $\S 255.1$ (c) ("When the advertisement represents that the endorser uses the endorsed product, the endorser must have been a bona fide user of it at the time the endorsement was given.").

${ }^{216}$ See id.

${ }^{217}$ Id. $\$ 255.0(\mathrm{e})$ ex. 7. 
Nothing in these default rules, however, affects the parties' right to contract for limits on the use of the avatars in exchange for value (financial, promotional, etc.) by the band. There is no First Amendment right to breach a contract.

The publisher of the game links the performers to iTunes or another site for purchasing music designated by the user. The publisher receives no compensation for these links but merely provides them as a convenience to the user. In this case, the publisher is not creating a link to propose a transaction. Like the newspaper and blog links, such interactivity does not result in a requirement for acquisition of publicity rights nor does it make the musician an endorser of the music or music service.

The publisher of the game directly or indirectly receives payments for links or clicks to a particular vendor that sells the music played in the game and merchandise worn by the avatars. Users are encouraged to buy from their favorite musicians while playing the game. In this case, the publisher is now proposing a commercial transaction. The publisher would need the express permission of each musician identified. The musician, in turn, would be subject to the requirements under the FTC Act because the musician is essentially endorsing the publisher as merchandise vendor as well as the particular products associated with the musician's avatar. ${ }^{218}$

The game play includes scenes where a musician's avatar is shown selecting a particular restaurant to feed the band after a concert. If this is part of the narrative of the game, no publicity rights are required and the musician will not be considered as providing an endorsement. Where the publisher receives payment for selecting a particular restaurant to show in such sequence, the use of the musician's avatar is a commercial use requiring express publicity rights. When the musician provides publicity rights for such use, the musician is an endorser of the goods or services identified.

\section{Example 7:}

A mobile phone application (app) allows the camera to take pictures of objects and people. From a distance greater than ten feet, the app can identify individuals using facial recognition software, and goods, such as clothing, from information contained in that good (which may include RFID technology, digital fingerprinting, or other data systems). Information in the app database allows the camera to open merchant websites related to the individuals and goods photographed. ${ }^{219}$

If the app provides only product information without regard to the individual photographed, there is no proposed commercial transaction and no action suggesting an endorsement. Neither right would be implicated.

${ }^{218} I d . \S 255.1(\mathrm{c})$.

${ }^{219}$ While such a technology may raise considerable privacy concerns that are matters of first impression, such issues are beyond the scope of this Article. 
If the app worked only on those celebrities who agreed to be part of the database, such agreement would necessarily include the applicable rights of publicity. Such celebrities should be considered endorsers of the products they presented in the system.

If the app disclosed what goods a celebrity was wearing and identified the particular products with the person photographed, such disclosure would be comparable to that of a fashion magazine. No rights of publicity or treatment as an endorser would be required.

If the app disclosed what goods a celebrity was wearing, identified the particular products with the person photographed, and allowed the consumer to directly purchase those goods, then if the app publisher also received direct or indirect compensation for the transactions which occurred, the app publisher would be required to acquire the publicity rights of each person portrayed. Each person should therefore be governed as an endorser of her associated products.

\section{Example 8:}

A video game is provided to the public for free with in-game tokens for purchase. ${ }^{220}$ Using the in-game payments, a player can purchase an avatar of the player's favorite musician or athlete. More popular avatars are sold for a premium price.

This situation is perhaps the most challenging intersection of commercial law and publicity rights. Absent any additional goods or services, the publication of the avatar alone is not in conjunction with goods or services and therefore not subject to any consent of the participant, notwithstanding the direct payment for the participation.

If, instead, the avatars of musicians and athletes feature clothing or goods for which the publisher has received any compensation, then that use constitutes a commercial exploitation of the avatar by the publisher for such goods. For example, if the musician's avatar is wearing a shirt with a popular soft drink logo, and the soft drink manufacturer paid for the placement of the trademark on the avatar, then the use is no longer merely editorial in nature. It is now a commercial use, requiring consent of the person identified as the avatar and accuracy as to the endorsement under the FTC Endorsement Guidelines.

If, instead, the publisher hyperlinks the avatars to commercial websites so that the player can consummate purchases using the avatar for which the publisher receives direct or indirect compensation, then this integration of the avatar and the commercial transaction is a use proposing a commercial transaction, requiring consent of the person identified as the avatar and accuracy as to the endorsement under the FTC Endorsement Guidelines.

${ }^{220}$ See, e.g., Blue Carreon, To Succeed in Retail You Have to Become Like Jennifer Lopez or Justin Timberlake, FORBES (Nov. 18, 2011, 9:21 AM), http://www.forbes.com/ sites/bluecarreon/2011/11/18/to-succeed-in-retail-you-have-to-become-like-jennifer-lopezor-justin-timberlake/. 
These examples are illustrative. There are a myriad of technological ways for a publisher of content to use the identity of individuals without their consent. When such use involves payment to that publisher from an advertiser or seller of goods and services, it becomes subject to publicity rights. If the publisher enables the player or consumer to use the identity to make a purchase or engage in commercial activities with goods or services and the publisher receives some direct or indirect compensation for such interactivity, then the publisher must acquire the publicity rights for such use. If there is no commercial activity or compensation to the publisher, then no permission is required.

Once consent has been given, it may include compensation for the publicity rights. If so, then the compensation for endorsement should be disclosed.

The ubiquity of the Internet should be used to make the disclosure more efficient, accessible, and resilient. Any party who has an obligation as an endorser should be required to make the information regarding the existence of the endorsement relationship publicly available on a permanent website, such as the primary website associated with the medium in which the advertisement or endorsement occurred. For interactive digital media, the link should also be integrated directly into the interactive media in question. Having the information in a permanent and more readily accessible form will increase consumer access to accurate information, one of the many goals of the First Amendment.

\section{CONCLUSION}

By using the intersection of existing trade law with the traditional publicity rights doctrine, the developing law of cyberspace can be applied to digital interactive media in predictable ways designed to protect against consumer fraud and protect the legitimate commercial interests of endorsers without impinging on the First Amendment. The system requires the more granular analysis that courts and regulators have applied in traditional media for decades.

By using the core principles of existing law, the concerns about technological innovation diminish and continued advancement of free speech can be promoted. The FTC and FCC provide an established road map to follow. If publicity rights doctrine is properly understood and used in a manner consistent with commercial speech jurisprudence, much of the tension between publicity rights and the First Amendment can be reduced, and the content system can be maintained to address the constantly changing landscape of interactive digital media. 